\title{
Canopy-scale flux measurements and bottom-up emission estimates of volatile organic compounds from a mixed oak and hornbeam forest in northern Italy
}

\author{
W. Joe F. Acton ${ }^{1}$, Simon Schallhart ${ }^{2}$, Ben Langford ${ }^{3}$, Amy Valach ${ }^{1,3}$, Pekka Rantala ${ }^{2}$, Silvano Fares ${ }^{4}$, \\ Giulia Carriero $^{5}$, Ralf Tillmann ${ }^{6}$, Sam J. Tomlinson ${ }^{3}$, Ulrike Dragosits ${ }^{3}$, Damiano Gianelle ${ }^{7,8}$, C. Nicholas Hewitt ${ }^{1}$, \\ and Eiko Nemitz ${ }^{3}$ \\ ${ }^{1}$ Lancaster Environment Centre, Lancaster University, Lancaster, LA1 4YQ, UK \\ ${ }^{2}$ Division of Atmospheric Sciences, Department of Physics, University of Helsinki, \\ Gustaf Hällströmin katu 2, 00560 Helsinki, Finland \\ ${ }^{3}$ Centre for Ecology \& Hydrology, Bush Estate, Penicuik, Midlothian, EH26 0QB, UK \\ ${ }^{4}$ Research Centre for Soil-Plant System, Council for Agricultural Research and Economics, \\ Rome, Italy \\ ${ }^{5}$ Institute for Plant Protection CNR Research Area - Building E, Via Madonna del Piano 10, \\ 50019 Sesto Fiorentino, Italy \\ ${ }^{6}$ Institute of Energy and Climate Research, IEK-8: Troposphere, Research Centre Jülich, \\ 52425 Jülich, Germany \\ ${ }^{7}$ Sustainable Agro-ecosystems and Bioresources Department, Research and Innovation Centre, \\ Fondazione Edmund Mach, 38010 S. Michele all'Adige, Italy \\ ${ }^{8}$ Foxlab Joint CNR-FEM Initiative, Via E. Mach 1, 38010 San Michele all'Adige, Italy \\ Correspondence to: Eiko Nemitz (en@ceh.ac.uk)
}

Received: 24 September 2015 - Published in Atmos. Chem. Phys. Discuss.: 27 October 2015

Revised: 5 April 2016 - Accepted: 16 May 2016 - Published: 10 June 2016

\begin{abstract}
This paper reports the fluxes and mixing ratios of biogenically emitted volatile organic compounds (BVOCs) $4 \mathrm{~m}$ above a mixed oak and hornbeam forest in northern Italy. Fluxes of methanol, acetaldehyde, isoprene, methyl vinyl ketone + methacrolein, methyl ethyl ketone and monoterpenes were obtained using both a proton-transfer-reaction mass spectrometer (PTR-MS) and a proton-transfer-reaction timeof-flight mass spectrometer (PTR-ToF-MS) together with the methods of virtual disjunct eddy covariance (using PTR-MS) and eddy covariance (using PTR-ToF-MS). Isoprene was the dominant emitted compound with a mean daytime flux of $1.9 \mathrm{mg} \mathrm{m}^{-2} \mathrm{~h}^{-1}$. Mixing ratios, recorded $4 \mathrm{~m}$ above the canopy, were dominated by methanol with a mean value of $6.2 \mathrm{ppbv}$ over the 28-day measurement period. Comparison of isoprene fluxes calculated using the PTR-MS and PTRToF-MS showed very good agreement while comparison of the monoterpene fluxes suggested a slight over estimation of
\end{abstract}

the flux by the PTR-MS. A basal isoprene emission rate for the forest of $1.7 \mathrm{mg} \mathrm{m}^{-2} \mathrm{~h}^{-1}$ was calculated using the Model of Emissions of Gases and Aerosols from Nature (MEGAN) isoprene emission algorithms (Guenther et al., 2006). A detailed tree-species distribution map for the site enabled the leaf-level emission of isoprene and monoterpenes recorded using gas-chromatography mass spectrometry (GC-MS) to be scaled up to produce a bottom-up canopy-scale flux. This was compared with the top-down canopy-scale flux obtained by measurements. For monoterpenes, the two estimates were closely correlated and this correlation improved when the plant-species composition in the individual flux footprint was taken into account. However, the bottom-up approach significantly underestimated the isoprene flux, compared with the top-down measurements, suggesting that the leaf-level measurements were not representative of actual emission rates. 


\section{Introduction}

The term volatile organic compound (VOC) describes a broad range of chemical species emitted from natural and anthropogenic sources into the atmosphere. VOCs emitted from the biosphere are commonly termed biogenic VOCs (BVOCs). Of the BVOCs, isoprene is almost certainly the dominant species globally with an estimated annual emission of 535-578 $\times 10^{12} \mathrm{~g} \mathrm{C}$ (Arneth et al., 2008; Guenther et al., 2012). Isoprene, along with larger terpenoids, is the BVOC that has received the most attention in the literature to date. Although isoprene is the most commonly measured BVOC, global emission estimates of isoprene continue to differ and there are still large uncertainties associated with the emission estimates of many other compounds. For example, annual monoterpene emission estimates vary between $32 \times 10^{12}$ and $127 \times 10^{12} \mathrm{~g} \mathrm{C}$ (Arneth et al., 2008). A better understanding of how emissions change with land cover, temperature, soil moisture and solar radiation is required to constrain model descriptions of the effects of BVOCs on atmospheric chemistry in the past, present and future (Monks et al., 2009).

$\mathrm{BVOCs}$ are a major source of reactive carbon into the atmosphere and as such exert an influence on both climate and local air quality. BVOCs are oxidized primarily by the hydroxyl radical $(\mathrm{OH})$, itself formed by the photolysis of ozone to form peroxide radicals $\left(\mathrm{RO}_{2}\right)$. In the presence of $\mathrm{NO}_{x}(\mathrm{NO}$ and $\mathrm{NO}_{2}$ ) these $\mathrm{RO}_{2}$ radicals can oxidize $\mathrm{NO}$ to $\mathrm{NO}_{2}$, which may undergo photodissociation leading to the net formation of tropospheric ozone (Fehsenfeld et al., 1992). Tropospheric ozone can then impact human health, forest productivity and crop yields (Royal Society, 2008; Ashmore, 2005). In addition, BVOC species contribute significantly to the formation of secondary organic aerosol (SOA) in the atmosphere. This affects climate both directly and indirectly by the scattering of solar radiation and by acting as cloud condensation nuclei. The formation of cloud condensation nuclei leads to increased cloud cover and therefore an altering of the Earth's albedo (Hallquist et al., 2009).

The Bosco Fontana campaign was carried out as a part of the ÉCLAIRE (Effects of Climate Change on Air Pollution and Response Strategies for European Ecosystems) EC FP7 project to study the surface-atmosphere exchange within a semi-natural forest, situated within one of the most polluted regions in Europe, and its interaction with air chemistry. During the Bosco Fontana campaign, VOC fluxes and mixing ratios were measured $4 \mathrm{~m}$ above the canopy of a semi-natural forest situated in the Po Valley, northern Italy $\left(45^{\circ} 11^{\prime} 51^{\prime \prime} \mathrm{N}\right.$, $10^{\circ} 44^{\prime} 31^{\prime \prime}$ E), during June and July 2012 . The Po Valley experiences high levels of anthropogenic pollution caused by its proximity to the city of Milan's high levels of industrial and traffic-related pollutant emissions, intensive agriculture and periods of stagnant air flow caused by the Alps to the north and west and the Apennines to the south (Bigi et al., 2011; Decesari et al., 2014).
In order to make accurate air quality predictions, precise regional and global models of BVOC emission are necessary. The modelling of BVOC emission at regional and global scales is generally dependent upon species-specific emission factors for the BVOCs of interest (Guenther et al., 2006; Steinbrecher et al., 2009). These emission factors are usually determined by the measurement of BVOC emission at a leaf level and at standard conditions (generally a leaf temperature of $30^{\circ} \mathrm{C}$ and $1000 \mu \mathrm{mol} \mathrm{m}^{-2} \mathrm{~s}^{-1}$ PAR). It is, however, important that leaf-level BVOC emission factors accurately represent canopy-scale emissions. Here we report the fluxes and mixing ratios of a range of BVOCs recorded from mixed mesophile forest at the Bosco Fontana field site. We compare BVOC flux calculation from above-canopy eddy covariance measurements using both a proton-transfer-reaction mass spectrometer (PTR-MS) and a proton-transfer-reaction time-of-flight mass spectrometer (PTR-ToF-MS) with isoprene and monoterpene fluxes obtained by scaling up leaflevel emission factors using the Model of Emissions of Gases and Aerosols from Nature (MEGAN) to produce a canopyscale bottom-up modelled flux estimate. We further explore the potential of accounting for the spatial tree-species distribution for improving the comparison between top-down and bottom-up approaches, in what we believe is the first approach of its type.

\section{Methods}

\subsection{Site description}

Measurements were taken at a site within the Bosco Fontana Nature Reserve $\left(45^{\circ} 11^{\prime} 51^{\prime \prime} \mathrm{N}, 10^{\circ} 44^{\prime} 31^{\prime \prime} \mathrm{E}\right)$, a 233 ha area of semi-natural woodland situated in the municipality of Marmirolo in the Po Valley. The forest canopy had an average height of approximately $28 \mathrm{~m}$ and was principally comprised of Carpinus betulus (hornbeam) and three oak species Quercus robur (pedunculate oak), Quercus cerris (turkey oak) and the introduced Quercus rubra (northern red oak) (Dalponte et al., 2007). In the centre of the forest there was a cleared area containing a seventeenth-century hunting lodge surrounded by hay meadows. The surrounding area was predominantly arable farmland with some pastures to the north and west and a reservoir to the north-west. The city of Mantova lies approximately $5 \mathrm{~km}$ to the south-east, with the small towns of Marmirolo, Soave and Sant'Antonio approximately $2 \mathrm{~km}$ north, $1 \mathrm{~km}$ west and $3 \mathrm{~km}$ east respectively. A $42 \mathrm{~m}$ measurement tower was situated near the centre of the forest to the south-west of the central hay meadows. The measurement tower was ca. $760 \mathrm{~m}$ from the edge of the forest in the direction of the easterly wind that dominated during this measurement period. 


\subsection{PTR-MS and PTR-ToF-MS set-up and measurement procedure}

In order to record BVOC fluxes and concentrations, both a high-sensitivity PTR-MS (Ionicon Analytik GmbH, Innsbruck, described in detail by Blake et al., 2009; de Gouw and Warneke 2007; Hansel et al., 1995; Lindinger et al., 1998) and a high-resolution PTR-ToF-MS (Ionicon Analytik $\mathrm{GmbH}$, Innsbruck, as described by Graus et al., 2010; Jordan et al., 2009) were used, together with a sonic anemometer (Gill HS, Gill Instruments Ltd, UK). The PTR-MS was equipped with a quadrupole mass analyser and three turbo molecular pumps (Varian). The Silcosteel inlet and internal tubing were heated to avoid condensation of BVOCs onto internal surfaces. The application of PTR-MS to atmospheric measurements has previously been described by Hewitt et al. (2003) and Hayward et al. (2002).

The sonic anemometer was situated $32 \mathrm{~m}$ above the ground on the north-west corner of the tower. This measurement height was chosen due to the fetch restrictions. Fluxes of sensible heat and momentum were compared with a flux measurement at the top of the tower $(42 \mathrm{~m})$ and were on average $15 \%$ larger for sensible heat and $5 \%$ for momentum (Finco et al., 2016). It is unclear whether this reflects differences in fetch, instrumentation or the effect of measuring within the surface roughness layer, but it is possible that fluxes reported here are slightly overestimated for this reason. The angle of attack was uncorrelated with wind direction suggesting that there was no local influence on the wind flow. Both the PTRMS and the PTR-ToF-MS were housed in an air-conditioned cabin at the base of the tower. The PTR-MS subsampled via a ca. $10 \mathrm{~cm}, 1 / 8$ inch (O.D.) PTFE tube (I.D.: $1 \mathrm{~mm}$, flow rate: $300 \mathrm{~mL} \mathrm{~min}^{-1}$, residence time: $0.04 \mathrm{~s}$ and with a Reynolds number inside the tube of ca. 258, indicating laminar flow but the very short residence time means that this does not provide the limiting factor for the overall response time of the measurement system) from a 0.5 inch O.D. PTFE common inlet line (I.D. $3 / 8$ inch), heated to avoid condensation, which led from ca. $10 \mathrm{~cm}$ below the sonic anemometer to the cabin. Solenoid valves were used to switch between the sample line and zero air, which was generated by passing ambient air through a glass tube packed with platinum catalyst powder heated to $200^{\circ} \mathrm{C}$. The PTR-ToF-MS subsampled via a 3-way valve from the common inlet line; $0.5 \mathrm{~L} \mathrm{~min}^{-1}$ was pumped through a $1 / 8$ inch (O.D.) and $1 / 16$ inch (O.D.) capillary (together ca. $20 \mathrm{~cm}$ long), with $30 \mathrm{~mL} \mathrm{~min}^{-1}$ entering the instrument and the remaining flow being sent to an exhaust. The common inlet line had a flow rate of ca. $63 \mathrm{~L} \mathrm{~min}^{-1}$, giving a Reynolds number of ca. 9700 which indicates a turbulent flow. There was no observable influence of the high flow rate on readings from the sonic anemometer, even during periods of relatively low turbulence. Data from both the PTR-MS and the sonic anemometer were logged onto a laptop using a programme written in LabVIEW (National Instruments, Austin, Texas, USA).
The PTR-MS was operated continuously throughout the measurement campaign with interruptions for the tuning of the instrument and refilling of the water reservoir. PTRMS settings were controlled so that the reduced electric field strength $(E / N$, where $E$ is the electric field strength and $N$ the buffer gas density) was held at $122 \mathrm{Td}$ $\left(1.22 \times 10^{-19} \mathrm{~V} \mathrm{~m}^{-2}\right)$, with drift tube pressure, temperature and voltage maintained at $2.1 \mathrm{mbar}, 45^{\circ} \mathrm{C}$ and $550 \mathrm{~V}$ respectively. The primary ions and the first water cluster were quantified indirectly from the isotope peaks at $m / z 21\left(\mathrm{H}_{3}{ }^{18} \mathrm{O}^{+}\right)$ and $m / z 39\left(\mathrm{H}_{3}{ }^{18} \mathrm{O} . \mathrm{H}_{2} \mathrm{O}^{+}\right)$respectively. The inferred count rate of $\mathrm{H}_{3} \mathrm{O}^{+}$ions over the course of the campaign varied between $1.33 \times 10^{6}$ and $9.00 \times 10^{6}$ counts s$^{-1} . \mathrm{O}_{2}^{+}(\mathrm{m} / z 32)$ was kept below $1 \%$ of the primary ion count throughout the campaign in order to limit ionization of VOCs through charge transfer reactions with $\mathrm{O}_{2}^{+}$and minimize the contribution of the $\mathrm{O}_{2}^{+}$isotope $\left({ }^{16} \mathrm{O}^{17} \mathrm{O}^{+}\right)$to $m / z 33$.

During PTR-ToF-MS operation the drift tube temperature was held at $60^{\circ} \mathrm{C}$ with $600 \mathrm{~V}$ applied across it. The drift tube pressure was 2.3 mbar resulting in an $E / N$ of $130 \mathrm{Td}$. A more detailed description of the PTR-ToF-MS operation is provided by Schallhart et al. (2016).

The PTR-MS was operated in three modes: the instrument measured zero air for $5 \mathrm{~min}$ followed by $25 \mathrm{~min}$ in flux mode, 5 min in scan mode and then a final 25 min in flux mode. While in flux mode, 11 protonated masses were monitored sequentially: $\mathrm{m} / z 21$ the hydronium ion isotope, $m / z 39$ a water cluster isotope and 9 masses relating to VOCs: $m / z 33$, $45,59,61,69,71,73,81$ and 137 . The mass spectral peaks at $m / z 21$ and 39 were analysed with a $0.2 \mathrm{~s}$ dwell time $(\tau)$. For the nine VOC species $\tau=0.5 \mathrm{~s}$ was used in order to increase the instrumental sensitivity to these masses. This gave a total scan time of $4.9 \mathrm{~s}$ and the acquisition of ca. 306 data points in each $25 \mathrm{~min}$ averaging period. The response time for this instrument, assessed during previous studies and laboratory tests, is ca. $0.5 \mathrm{~s}$, and dwell times were chosen to match this time in order to minimize overall duty cycle loss due to $m / z$ switching. The uncertainty caused by disjunct sampling was calculated and found to cause a $0.17 \%$ error in the flux estimation (see Supplement information for details).

Identification of the compounds observed at each of these masses is complicated by the fact that PTR-MS only allows the identification of nominal masses, therefore it is impossible to distinguish between isobaric compounds. As such, there may be more than one compound contributing to each of the measured masses; Table 1 displays the masses monitored and the compounds likely to be contributing to each mass together with the exact masses observed at each unit mass using the PTR-ToF-MS, which has much greater mass resolution than the quadrupole PTRMS instrument. It was assumed that the dominant contributions at $m / z 33,45,59,61,69,71,73,81$ and 137 were from protonated methanol, acetaldehyde (ethanal), acetone (propanone), acetic acid (ethanoic acid), isoprene (2-methyl- 
Table 1. Unit masses measured using the PTR-MS during the ÉCLAIRE campaign at Bosco Fontana and the exact masses observed using the PTR-ToF-MS. Where the PTR-MS sensitivity was calculated directly from a compound in the calibration standard, this compound is indicated in brackets. At $m / z, 61$ and 71 the sensitivity was calculated from a transmission curve.

\begin{tabular}{|c|c|c|c|c|}
\hline $\begin{array}{l}\text { Unit mass } \\
\text { (PTR-MS) }\end{array}$ & $\begin{array}{r}\text { Exact mass } \\
(\text { PTR-ToF-MS) }\end{array}$ & $\begin{array}{l}\text { Contributing } \\
\text { compound(s) }\end{array}$ & Formula & $\begin{array}{l}\text { PTR-MS sensitivity } \\
\quad\left(\text { ncps ppbv }{ }^{-1}\right)\end{array}$ \\
\hline 21 & 21.023 & Water isotope & $\mathrm{H}_{3}^{18} \mathrm{O}^{+}$ & - \\
\hline \multirow[t]{2}{*}{33} & 32.997 & Oxygen isotope & $\mathrm{O}^{17} \mathrm{O}^{+}$ & 11.60 (methanol) \\
\hline & 33.033 & Methanol & $\mathrm{CH}_{5} \mathrm{O}^{+}$ & \\
\hline 39 & 39.033 & Water cluster & $\mathrm{H}_{5} \mathrm{O}^{18} \mathrm{O}^{+}$ & - \\
\hline \multirow[t]{2}{*}{45} & 44.997 & Protonated carbon dioxide & $\mathrm{C}_{1} \mathrm{H}_{1} \mathrm{O}_{2}^{+}$ & 9.90 (acetaldehyde) \\
\hline & 45.033 & Acetaldehyde & $\mathrm{C}_{2} \mathrm{H}_{5} \mathrm{O}^{+}$ & \\
\hline \multirow[t]{2}{*}{59} & 59.049 & Acetone & $\mathrm{C}_{3} \mathrm{H}_{7} \mathrm{O}^{+}$ & 8.82 (acetone) \\
\hline & 59.049 & Propanal & $\mathrm{C}_{3} \mathrm{H}_{7} \mathrm{O}^{+}$ & \\
\hline 61 & 61.028 & Acetic acid & $\mathrm{C}_{2} \mathrm{H}_{5} \mathrm{O}_{2}$ & 8.40 (transmission curve) \\
\hline \multirow[t]{3}{*}{69} & 69.0699 & Isoprene & $\mathrm{C}_{5} \mathrm{H}_{9}^{+}$ & 3.80 (isoprene) \\
\hline & 69.0699 & 2-Methyl-3-buten-2-ol fragment & $\mathrm{C}_{5} \mathrm{H}_{0}^{+}$ & \\
\hline & 69.0699 & Methyl butanal fragment & $\mathrm{C}_{5} \mathrm{H}_{9}^{+}$ & \\
\hline \multirow[t]{3}{*}{71} & 71.049 & Methyl vinyl ketone & $\mathrm{C}_{4} \mathrm{H}_{7} \mathrm{O}^{+}$ & 5.29 (transmission curve) \\
\hline & 71.049 & Methacrolein & $\mathrm{C}_{4} \mathrm{H}_{7} \mathrm{O}^{+}$ & \\
\hline & 71.085 & Unknown & $\mathrm{C}_{5} \mathrm{H}_{11}^{+}$ & \\
\hline \multirow[t]{4}{*}{73} & 73.026 & Unknown & $\mathrm{C}_{3} \mathrm{H}_{5} \mathrm{O}_{2}^{+}$ & 5.87 (Methyl ethyl ketone) \\
\hline & 73.047 & Unknown & Unknown & \\
\hline & 73.065 & Methyl ethyl ketone & $\mathrm{C}_{4} \mathrm{H}_{9} \mathrm{O}^{+}$ & \\
\hline & 73.065 & Butanal & $\mathrm{C}_{4} \mathrm{H}_{9} \mathrm{O}^{+}$ & \\
\hline \multirow[t]{4}{*}{81} & 80.997 & Unknown & $\mathrm{C}_{4} \mathrm{H}_{1} \mathrm{O}_{2}^{+}$ & $1.59(\alpha$-pinene fragment $)$ \\
\hline & 81.033 & Unknown & $\mathrm{C}_{5} \mathrm{H}_{5} \mathrm{O}^{+}$ & \\
\hline & 81.070 & Monoterpene fragment & $\mathrm{C}_{6} \mathrm{H}_{9}^{+}$ & \\
\hline & 81.070 & Hexenal fragment & $\mathrm{C}_{6} \mathrm{H}_{9}^{+}$ & \\
\hline \multirow[t]{2}{*}{137} & 137.056 & Unknown & Unknown & 0.16 ( $\alpha$-pinene $)$ \\
\hline & 137.133 & Monoterpenes & $\mathrm{C}_{10} \mathrm{H}_{17}^{+}$ & \\
\hline
\end{tabular}

1,3-butadiene), methyl vinyl ketone (MVK, butenone) and methacrolein (MACR, 2-methylprop-2-enal), methyl ethyl ketone (MEK, butanone), a monoterpene mass spectral fragment and monoterpenes respectively. A further contribution to $m / z 71$, recently identified, are isoprene hydroxy hydroperoxides (ISOPOOH, Rivera-Rios et al., 2014). However, the concentrations of this intermediate are small if $\mathrm{NO}_{x}$ concentrations are high and therefore are likely to be negligible at this site, where $\mathrm{NO}_{x}$ concentrations were large (Finco et al., 2016).

\subsubsection{PTR-MS calibration}

The PTR-MS was calibrated using a gas standard (Ionicon Analytic $\mathrm{GmbH}$, Innsbruck) containing 17 VOCs at a mixing ratio by volume of approximately $1 \times 10^{-6}$ (ca. 1 ppmv). The protonated mass of the VOCs ranged from $m / z 31$ (formaldehyde, $\mathrm{CH}_{3} \mathrm{O}^{+}$) to $m / z, 181(1,2,4-$ trichlorobenzene, $\left.\mathrm{C}_{6} \mathrm{H}_{4} \mathrm{Cl}_{3}^{+}\right)$. Methanol $(\mathrm{m} / z$ 33), acetaldehyde $(m / z 45)$, acetone $(m / z 59)$, isoprene $(m / z 69)$, MEK $(m / z$ 73) and the monoterpene $\alpha$-pinene $(\mathrm{m} / z \quad 81$ and $m / z$ 137) were present in the calibration gas standard, al- lowing sensitivities to be calculated directly. Due to reduced quadrupole transmission for high masses, monoterpenes were quantified using the fragment ion at $m / z 81$. For compounds not contained in the gas standard (acetic acid $(m / z$ 61) and MVK and MACR $(m / z$ 71)) empirical sensitivities were calculated. A relative transmission curve was created using the instrumental sensitivities calculated from the masses present in the standard and from this curve, sensitivities for the unknown masses were calculated (Davison et al., 2009; Taipale et al., 2008). Error in calibration using the gas standard was assumed to be below $15 \%$, whereas relative errors in calibrations using the relative transmission approach are $<30 \%$ (Taipale et al., 2008). The change in instrumental sensitivity from before the campaign to the end of the campaign was $+1.9,-2,-2.1,-0.3$ and $-0.7 \mathrm{ncps} \mathrm{ppbv}^{-1}$ for methanol, acetaldehyde, acetone, isoprene and methyl ethyl ketone respectively.

\subsubsection{PTR-ToF-MS calibration}

Background measurements of the PTR-ToF-MS were made up to three times a day using zero air generated by a cus- 
tom made catalytic converter. Calibrations were made using a calibration gas (Appel Riemer Environmental Inc., USA) which contained 16 compounds, with masses ranging from 33 to $180 \mathrm{amu}$. For VOCs not included in the calibration standard, the average instrument sensitivities towards the known $\mathrm{C}_{x} \mathrm{H}_{y}, \mathrm{C}_{x} \mathrm{H}_{y} \mathrm{O}_{z}$ or $\mathrm{C}_{x} \mathrm{H}_{y} \mathrm{~N}_{z}$ compound families were used.

\subsection{Calculation of volume mixing ratios}

Mixing ratios by volume were calculated from data generated using the PTR-MS using a programme written in LabVIEW (National Instruments, Austin, Texas, USA). Mixing ratios by volume $\left(\chi_{\text {VOC }}\right)$ were calculated from the raw PTR-MS data (in counts per second, cps) using a method based on those of Taipale et al. (2008) and Tani et al. (2004).

$\chi_{\mathrm{VOC}}=\frac{I\left(\mathrm{RH}^{+}\right)_{\mathrm{norm}}}{S_{\mathrm{norm}}}$,

where $\mathrm{S}_{\text {norm }}$ is the normalized sensitivity and $I\left(\mathrm{RH}^{+}\right)_{\text {norm }}$ represents the background corrected normalized count rate (ncps) for the protonated compound $R$, which was calculated as shown below.

$$
\begin{aligned}
& I\left(\mathrm{RH}^{+}\right)_{\text {norm }}= \\
& I\left(\mathrm{RH}^{+}\right)\left(\frac{I_{\text {norm }}}{I\left(\mathrm{H}_{3} \mathrm{O}^{+}\right)+I\left(\mathrm{H}_{3} \mathrm{O}^{+} \mathrm{H}_{2} \mathrm{O}\right)}\right)\left(\frac{p_{\text {norm }}}{p_{\text {drift }}}\right) \\
& -\frac{1}{n} \sum_{i=1}^{n} I\left(\mathrm{RH}^{+}\right)_{\text {zero }, i} \\
& \left(\frac{I_{\text {norm }}}{I\left(\mathrm{H}_{3} \mathrm{O}^{+}\right)_{\text {zero }, i}+I\left(\mathrm{H}_{3} \mathrm{O}^{+} \mathrm{H}_{2} \mathrm{O}\right)_{\text {zero }, i}}\right)\left(\frac{p_{\text {norm }}}{p_{\text {drift, zero }, i}}\right),
\end{aligned}
$$

where $I\left(\mathrm{RH}^{+}\right), I\left(\mathrm{H}_{3} \mathrm{O}^{+}\right)$and $I\left(\mathrm{H}_{3} \mathrm{O}^{+} \mathrm{H}_{2} \mathrm{O}\right)$ represent the observed count rate for the protonated compound $R, \mathrm{H}_{3} \mathrm{O}^{+}$ and the $\mathrm{H}_{3} \mathrm{O}^{+} \mathrm{H}_{2} \mathrm{O}$ cluster respectively. Subscript zero refers to zero-air measurements, $n$ is the number of zero-air measurement cycles and $p_{\text {drift }}$ is the drift tube pressure. The drift tube pressure was normalized to $2 \mathrm{mbar}$ ( $p_{\text {norm }}$ ) and the sum of the primary ion and first water cluster was normalized to a count rate of $10^{6} \mathrm{cps}\left(I_{\text {norm }}\right)$. The compound-specific limit of detection (LoD) was calculated using the method described by Karl et al. (2003):

$\mathrm{LoD}=2 \times \frac{\sigma_{\text {Background }}}{S_{\text {VOC }}}$,

where $S_{\mathrm{VOC}}$ is the instrumental sensitivity to the VOC and $\sigma_{\text {Background }}$ is the mean background normalized count rate.

\subsection{Flux calculations from PTR-MS}

The 25 min PTR-MS flux files were inspected, and incomplete or disrupted files were removed. BVOC fluxes were then calculated using a programme also written in LabVIEW, based upon the virtual disjunct eddy covariance technique
(vDEC) developed by Karl et al. (2002), also termed continuous flow disjunct eddy covariance (Rinne et al., 2008). This method has been successfully applied in a number of studies (e.g. Davison et al., 2009; Langford et al., 2009; 2010a, b; Misztal et al., 2011; Rinne et al., 2007). This approach allows direct calculation of fluxes of atmospheric constituents, as with standard eddy covariance, yet in this case sampling of scalar concentrations is not continuous. The flux, $F_{x}$, for each compound was calculated using a covariance function between the vertical wind velocity, $w$, and the VOC mixing ratios, $\chi$ :

$F_{x}(\Delta t)=\frac{1}{N} \sum_{i=1}^{N} w^{\prime}\left(i-\Delta t / \Delta t_{w}\right) \chi^{\prime}(i)$,

where $\Delta t$ is the lag time between the PTR-MS concentration measurements and the vertical wind velocity measurements from a sonic anemometer, $\Delta t_{w}$ is the sampling interval between wind measurements $(0.1 \mathrm{~s}), N$ is the number of PTR-MS measurement cycles in each 25 min averaging period (typically 306 in our study) and primes represent the momentary deviations from the mean concentration or vertical wind speed (e.g. $w=w^{\prime}-\bar{w}$ ).

Variations in temperature, pressure and the performance of the sample line pump can cause small deviations in $\Delta t$. Therefore these values were calculated using a crosscorrelation function between $w$ ' and $\chi$ '. Lag times were calculated individually for each $\mathrm{m} / \mathrm{z}$ monitored by the PTR-MS by selecting the absolute maximum value of the covariance function within a $30 \mathrm{~s}$ time window (MAX method, Taipale et al., 2010). This analysis resulted in a clear isoprene flux but for most masses a high proportion of the data fell below the limit of detection. These data, especially in the case of acetone, showed a significant amount of flux values with the opposite sign, "mirroring" the true flux. These "mirrored" points occur when the measured flux is of comparable magnitude to the total random error of the system (Langford et al., 2015). As the cross-correlation maximum is likely to be an overestimate when the noise-to-signal ratio is greater than one, these points were substituted with fluxes calculated using a fixed lag time.

A histogram of isoprene lag times calculated using the MAX method is displayed in the Supplement, showing a clear maximum at $7.5 \mathrm{~s}$. Therefore $7.5 \mathrm{~s}$ was chosen as the isoprene-fixed lag time and fixed lag times for the other masses were calculated from the isoprene-fixed lag time, accounting for the dwell times of the different compounds in the measurement cycle.

\subsubsection{Flux quality assessment and potential losses}

In order to assess the quality of each 25 min flux file, the resultant fluxes were subjected to three quality checks following a two-dimensional coordinate rotation, which was applied to correct for tilting of the sonic anemometer (see Ta- 
ble $\mathrm{S} 1$ in the Supplement for a summary). Following the criteria of Langford et al. (2010a), data points were labelled if the mean friction velocity $\left(u_{*}\right)$ over the $25 \mathrm{~min}$ averaging period was found to be below $0.15 \mathrm{~m} \mathrm{~s}^{-1}$. Data falling below this threshold predominantly occurred at night when wind velocity reached a minimum. Detection limits for each 25 min flux file were calculated using a method based on that of Wienhold et al. (1994), as applied by Spirig et al. (2005), where the signal of the flux at the true lag is compared to the background noise of the covariance function. The 95th percentile of the covariance function in the lag range 150$180 \mathrm{~s}$ was calculated and flux files falling below this value were labelled as having fallen below the LoD. Finally data points underwent a stationarity test as described by Foken and Wichura (1996), which assessed the stability of the flux across the $25 \mathrm{~min}$ averaging period. Data points found to be generated from periods of non-stationarity were also labelled. Flux files in which all three tests were passed and where only the LoD test was failed were included in all further analyses. Files which failed the LoD test were included to prevent a positive bias being introduced to the results. Flux files failing the stationarity check or falling below the $u_{*}$ threshold were excluded from further analysis.

The integral turbulence characteristics were assessed using the FLUXNET criteria described by Foken et al. (2004). The turbulence at the Bosco Fontana field site was well developed with $87 \%$ of the data in the first three categories, defined by Foken et al. (2004) as suitable for fundamental research. Less than $1 \%$ of the data fell into category 9 , characterized as data to be excluded under all circumstances.

The flux losses in the virtual disjunct eddy covariance system were assessed. Loss of flux at frequencies higher than the PTR-MS response time and/or dwell time was corrected for using the method described by Horst (1997). Correction factors in the range 1.01-1.23 were calculated and applied to each 25 min flux file with a mean correction of $8.8 \%$. Rotating the coordinates in order to set the vertical mean wind velocity to 0 for each $25 \mathrm{~min}$ flux-averaging period and block averaging itself act as a high-pass flux filter (Moncrieff et al., 2004), leading to the loss of low-frequency fluxes. The loss of these low-frequency fluxes due to an insufficient averaging period is assessed in the Supplement. Sensible heat-flux data were averaged over 50, 75, 100 and 125 min before a coordinate rotation was applied and plotted against the sum of two, three, four and five $25 \mathrm{~min}$ coordinate rotated flux files respectively. The gradient of the fitted line between the two fluxes gives an estimate of the flux lost by the use of 25 min averaging periods. As is shown in Fig. S2, eddies with a time period between 25 and 125 min carry only an additional $2.8 \%$ of the sensible heat flux. Therefore if we assume that the frequency of VOC and sensible heat fluxes are comparable, $1.0-3.6 \%$ of the VOC flux is lost by limiting the averaging period to $25 \mathrm{~min}$. This correction has not been applied to the displayed data as it is so small.
The effect of the measurement tower (situated to the southeast of the sonic anemometer) on flux measurements was assessed in two ways. Firstly, the vertical rotation angle $(\theta)$ used to realign the anemometer to achieve zero average $w$ was plotted against wind direction (Fig. S4). No change in $\theta$ was observed when the wind came from the south-east, demonstrating that the tower did not affect $\theta$. Secondly, the potential of wake turbulence created by the tower was assessed using the method developed by Foken (2004). The quality of the turbulence within each flux-averaging period was assessed by calculating the percentage difference between the measured integral turbulence statistics of the vertical wind velocity and values modelled for an ideal set of conditions. Plotting the percentage difference between the measured and modelled values against wind direction (Fig. S4) showed that the tower had little effect on this percentage difference and thus on flux measurements (for a more detailed discussion, see Supplement). Therefore, flux-averaging periods, during which the wind was coming from the south-east, were not systematically excluded from further analysis.

The percentage of flux-averaging periods during which $>25 \%$ of the flux originated from outside the forest area was also assessed by footprint analysis and found to account for $26 \%$ of the data set. As the flux footprint moves with atmospheric stability, fluxes from outside the forest predominantly occurred during night-time conditions when emission rates were very small. Therefore it was not deemed necessary to specifically remove these data prior to further bulk analysis of the data set, although it is recognized that the $u_{*}$ filter criterion removed many of these measurements. A more detailed analysis of the effect of the tree-species composition within the footprint on measured and modelled fluxes is presented below.

\subsection{Flux calculations from PTR-ToF-MS}

BVOC fluxes were calculated from PTR-ToF-MS data using the eddy covariance (EC) method similar to that described above for the PTR-MS. The PTR-ToF-MS flux analysis differed in that the cross correlation between $w^{\prime}$ and $\chi^{\prime}$ was calculated using the method described by Park et al. (2013). Whilst in the PTR-MS measurement, the target compounds are predetermined through the measurement cycle, in the PTR-ToF-MS the entire high-resolution mass spectrum can be used to search for compounds that carry a flux. PTR-ToFMS data were analysed using the TOF Analyzer V2.45 as described by Müller et al. (2013) and TofTools (Junninen et al., 2010). An automated flux identification routine was then used to calculate the average of the absolute cross-covariance functions during a midday period. The maximum value was then automatically selected from the averaged spectrum and checked against the manually selected noise level $\left(10 \sigma_{\text {noise }}\right)$ to determine whether a flux was present.

The fluxes were filtered using the $70 \%$ stationary criteria as presented by Foken and Wichura (1996), as was ap- 
plied to the PTR-MS data and corrected for loss of highfrequency flux Horst (1997). For a more detailed description of the flux calculation from the PTR-ToF-MS see Schallhart et al. (2016).

\subsection{Leaf-level GC-MS measurements}

A portable gas exchange system equipped with a controlledenvironment $6-\mathrm{cm}^{2}$ broadleaf cuvette (LI6400, Li-COR, Lincoln, USA) was used to measure net photosynthetic rate $(A)$ and stomatal conductance $\left(g_{\mathrm{s}}\right)$ at basal conditions of PAR $\left(1000 \mu \mathrm{mol} \mathrm{m}^{-2} \mathrm{~s}^{-1}\right)$, leaf temperature $\left(30^{\circ} \mathrm{C}\right)$ and a $\mathrm{CO}_{2}$ concentration $(400 \mathrm{ppm})$ from fully expanded leaves. These conditions were comparable to those observed during the campaign where the average daytime temperature was $29^{\circ} \mathrm{C}$. While the cuvette is capable of reproducing ambient light and temperature conditions, unstable environmental conditions below the canopy make it difficult to achieve steadystate fluxes. BVOC emission was therefore recorded at basal conditions to ensure that steady-state fluxes could be obtained and to enable comparison between different individual measurements. When $A$ reached a steady state, the outlet tube from the leaf cuvette was replaced with a Teflon tube, and the airstream exiting from the cuvette was used to sample BVOCs (according to the methodology in Loreto et al., 2001) by adsorbing them onto a Silcosteel cartridge packed with $200 \mathrm{mg}$ of tenax (Supelco, PA, USA). Tenax is a very hydrophobic and adsorbent material with high thermal stability, generally used for trapping BVOC (Dettmer and Engewald, 2002). The flow rate through the leaf cuvette was maintained at $500 \mu \mathrm{mol} \mathrm{s}^{-1}$, and a subsample of $200 \mathrm{~mL} \mathrm{~min}^{-1}$ $\left(130 \mu \mathrm{mol} \mathrm{s}^{-1}\right)$ was pumped through the cartridge with an external pump (AP Buck pump VSS-1) for a total volume of $6 \mathrm{~L}$ of air. Blank samples of air without a leaf in the cuvette were collected every day before and after the BVOC samplings. Finally the cartridges were sealed and stored at $4^{\circ} \mathrm{C}$ until analysis.

The cartridges were analysed using a Perkin Elmer Clarus 580 gas chromatograph coupled with a Clarus 560 MassDetector and a thermal-desorber Turbo Matrix (Perkin Elmer Inc., Waltham, MA, USA). The gas chromatograph was equipped with an Elite-5-MS capillary column (30 m length, $250 \mu \mathrm{m}$ diameter and $0.25 \mu \mathrm{m}$ film thicknesses). The carrier gas was helium. The column oven temperature was kept at $40^{\circ} \mathrm{C}$ for $5 \mathrm{~min}$, then increased with a $5^{\circ} \mathrm{C} \mathrm{min}-1$ ramp to $250^{\circ} \mathrm{C}$ and maintained at $250^{\circ} \mathrm{C}$ for $5 \mathrm{~min}$. BVOC were identified using the National Institute of Standards and Technology (NIST) library provided with the gaschromatography mass spectrometry (GC-MS) Turbomass software. GC peak retention time was substantiated by analysis of parent ions and main fragments of the spectra. Commercially available reference standards (gaseous standards, Rivoira, Milan, Italy and liquid standards, Sigma Aldrich, Milan, Italy) were used to create the calibration curves and to quantify the emissions. To normalize the BVOC results, the quantities of terpenes collected from the empty cuvette (blanks) were subtracted from the plant emission results.

\subsection{Mapping tree-species distribution}

Tree-species distribution data were obtained from Dalponte et al. (2007) who used a combination of light detection and ranging (lidar) and hyperspectral data to develop a highresolution tree-species distribution map of the Bosco Fontana Nature Reserve.

The overall accuracy (kappa coefficient) of this species map is particularly high (0.89), considering the number of classes (23) and the number of training samples $(20 \%$ of the data are used in the training set and $80 \%$ in the test set) per class. The lidar channels provide relatively sparse information for discriminating between tree species, increasing the overall accuracy of the tree-species assignment using the hyperspectral data by only $1 \%$ but the lidar data significantly increase the accuracy of understory and underrepresented classes. The kappa coefficient of the main species is also very high (0.88-0.93) showing the effectiveness of this approach for species classification in a very complex forest with 20 different broad-leaf species, some of which, such as $Q$. cerris, $Q$. robur and $Q$. rubra, belong to the same genus. For a more detailed discussion of the mapping results and methodology see Dalponte et al. $(2007,2008)$.

\section{Results and discussion}

\subsection{Meteorological conditions}

The measurement campaign at Bosco Fontana ran from 1 June to 11 July 2012 (41 days) with data recorded using the PTR-MS from the 13 June to the 11 July 2012. The meteorological conditions recorded at the measurement site during this period are summarized in Fig. 1, times are reported in central European time (UTC + 1) as used throughout this paper. The campaign average flux footprint is displayed in Fig. 2. With the exception of two heavy thunderstorms, the first in the first week of June before measurements began and the second overnight on 6 July, there was no precipitation during the measurement period. During the measurement period, ambient temperature varied from a low of $14^{\circ} \mathrm{C}$ to a high of $35^{\circ} \mathrm{C}$, with temperatures lowest early in the campaign. Daily photosynthetically active radiation (PAR) peaked within the range $1890-2105 \mu \mathrm{mol} \mathrm{m}^{-2} \mathrm{~s}^{-1}$ and the relative humidity during the campaign varied between 29 and $90 \%$. Winds were generally easterly or north-westerly. For most of the campaign wind speeds were below $3.5 \mathrm{~m} \mathrm{~s}^{-1}$ but peaked at $5.6 \mathrm{~m} \mathrm{~s}^{-1}$ on 23 June, with the mean wind speed for the campaign period of $1.6 \mathrm{~m} \mathrm{~s}^{-1}$. 

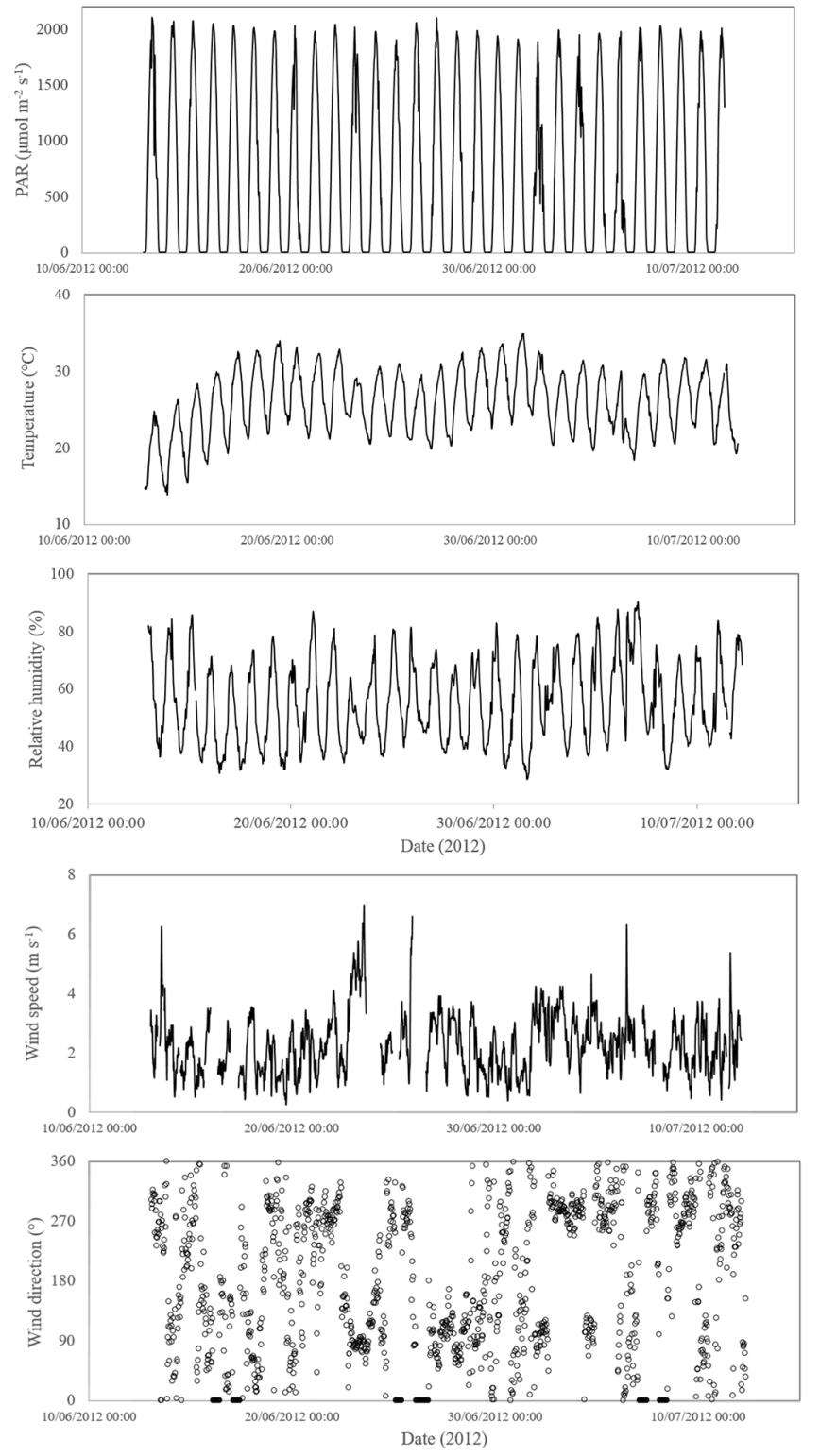

Figure 1. Time series of meteorological conditions recorded over the campaign period. From top to bottom: PAR $\left(\mu \mathrm{mol} \mathrm{m} \mathrm{m}^{-2} \mathrm{~s}^{-1}\right)$, air temperature $\left({ }^{\circ} \mathrm{C}\right)$, relative humidity $(\%)$, wind speed $\left(\mathrm{m} \mathrm{s}^{-1}\right)$ and wind direction $\left({ }^{\circ}\right)$.

\subsection{BVOC mixing ratios and fluxes}

BVOC fluxes were recorded at the Bosco Fontana site using both the PTR-MS and the PTR-ToF-MS. Unless stated, the results displayed here were calculated from measurements made using the PTR-MS. Data analysis was carried out with the aid of the R openair package (Carslaw and Ropkins, 2012; R Core Team, 2012). For a full discussion of all fluxes and concentrations recorded using the PTR-ToF-MS, see Schallhart et al. (2016).

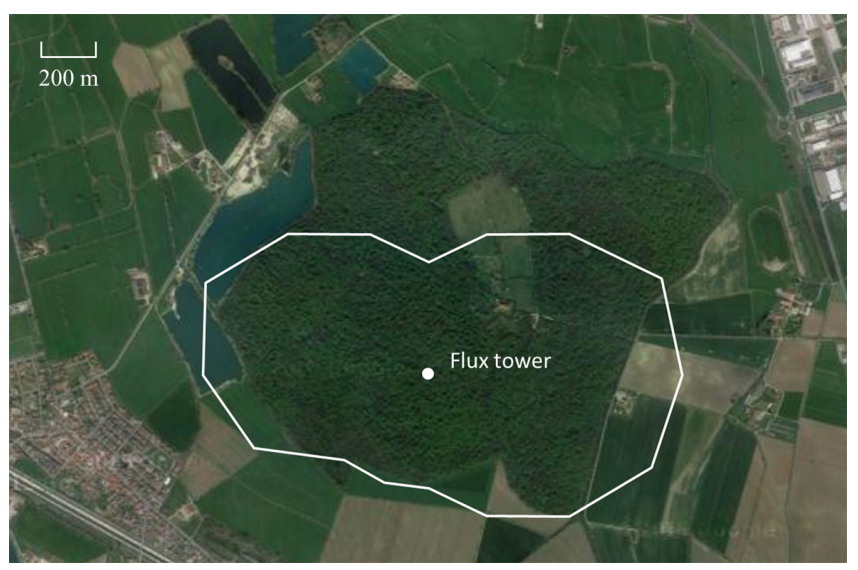

Figure 2. Satellite image (map data ${ }^{\odot}$ Google 2016) of the field site showing the flux tower and footprint containing $80 \%$ of the flux measured during the campaign (13 June-11 July 2012).

The mixing ratios of the eight BVOC species measured in flux mode using the PTR-MS are displayed in Fig. 3 and are summarized in Table 2 (for further details, see Fig. S6). These mixing ratios were calculated using the highfrequency flux measurements so the presented mixing ratios are averaged over $25 \mathrm{~min}$. The mixing ratio LoDs, calculated as described above (Karl et al., 2003; Langford et al., 2009; Misztal et al., 2011), were in the same range as those calculated on previous campaigns (Langford et al., 2009; Misztal et al., 2011) and, with the exception of isoprene for which the mixing ratio dropped towards zero at night, the recorded mixing ratios generally remained above their respective $\mathrm{LoD}$.

Table 3 summarizes the flux data recorded during the Bosco Fontana measurement campaign. Wind speeds decreased at night, leading to a large proportion of the nighttime data falling below the $u_{*}$ threshold of $0.15 \mathrm{~m} \mathrm{~s}^{-1}$. Consequently, average emission fluxes of all eight compounds are reported for the daytime period 10:00-15:00 LT as well as for the whole campaign. Large fluxes of $m / z, 69$ and $m / z 81$ (assigned to isoprene and monoterpenes respectively) were observed and are shown in Fig. 4. Fluxes of $m / z$ 33, 45, 59, 61, 71 and 73 (assigned to methanol, acetaldehyde, acetone, acetic acid, MVK + MACR and MEK respectively) were also observed, but these fluxes were weaker, leading to a high percentage of fluxes failing the LoD check. However, as is described by Langford et al. (2015), when these flux data are averaged to show the average diurnal cycle, it is appropriate to use a combined $\mathrm{LoD}$ value appropriate for the same period rather than the LoD attached specifically to each 25 min flux file. It is, however, essential that each individual flux period be processed carefully to avoid the introduction of a bias due to the use of the MAX method of time-lag identification. The $\mathrm{LoD}$ for the mean $(\overline{\mathrm{LoD}})$ decreases with the square root of the number of samples averaged $(N)$. 
Table 2. Summary of the BVOC mixing ratios (ppbv) recorded at $4 \mathrm{~m}$ above the forest canopy during the Bosco Fontana measurement campaign and limits of detection (LoD, ppbv), based on 25 min averages.

\begin{tabular}{lrrrrrrrr}
\hline$m / z$ & 33 & 45 & 59 & 61 & 69 & & 71 & 73 \\
\hline Compound & Methanol & Acetaldehyde & Acetone & Acetic acid & Isoprene & MVK+ MACR & MEK & Monoterpenes \\
\hline Max & 14.6 & 3.44 & 7.31 & 14.9 & 4.79 & 1.95 & 1.05 & 0.419 \\
Min & 2.13 & <OD & 1.18 & 0.396 & $<$ LOD & 0.083 & 0.097 & $<$ LOD \\
Mean & 6.16 & 1.46 & 3.24 & 1.92 & 1.07 & 0.506 & 0.454 & 0.198 \\
Standard deviation & 2.52 & 0.67 & 0.91 & 1.09 & 0.80 & 0.28 & 0.21 & 0.07 \\
Median & 5.69 & 1.30 & 3.14 & 1.73 & 0.934 & 0.506 & 0.428 & 0.199 \\
1st Quartile & 4.19 & 0.964 & 2.68 & 1.22 & 0.409 & 0.325 & 0.311 & 0.140 \\
3rd Quartile & 7.53 & 1.87 & 3.82 & 2.31 & 1.53 & 0.95 & 0.568 & 0.245 \\
LOD & 0.436 & 0.712 & 0.239 & 0.141 & 0.167 & 0.081 & 0.048 & 0.067 \\
\hline
\end{tabular}

Table 3. Summary of the BVOC fluxes $\left(\mathrm{mg} \mathrm{m}^{-2} \mathrm{~h}^{-1}\right)$ recorded during the Bosco Fontana field campaign based on $25 \mathrm{~min}$ values. Values in brackets cover the campaign period where data are available from both instruments to enable direct comparison (15 June-6 July and 15-25 June 2012 for isoprene and monoterpenes respectively).

\begin{tabular}{|c|c|c|c|c|c|c|c|c|c|c|}
\hline$m / z$ & 33 & 45 & 59 & 61 & 6 & & 71 & 73 & 8 & \\
\hline Compound & Methanol & Acetaldehyde & Acetone & Acetic acid & $\begin{array}{l}\text { Isoprene } \\
\text { PTR-MS }\end{array}$ & $\begin{array}{r}\text { Isoprene } \\
\text { PTR-ToF-MS }\end{array}$ & $\begin{array}{r}\text { MVK } \\
+ \text { MACR }\end{array}$ & MEK & $\begin{array}{r}\text { Monoterpenes } \\
\text { PTR-MS }\end{array}$ & $\begin{array}{r}\text { Monoterpenes } \\
\text { PTR-ToF-MS }\end{array}$ \\
\hline Max emission flux & 0.492 & 0.436 & 0.585 & 0.328 & $9.867(9.867)$ & 9.195 (9.195) & 0.641 & 0.181 & $0.478(0.478)$ & $0.609(0.603)$ \\
\hline $\begin{array}{l}\text { Max deposition } \\
\text { flux }\end{array}$ & -1.589 & -0.335 & -0.692 & -0.876 & $-0.238(-0.238)$ & $-0.305(-0.305)$ & -0.457 & -0.128 & $-0.167(-0.167)$ & $-0.065(-0.057)$ \\
\hline 1st Quartile & -0.032 & -0.011 & -0.029 & -0.044 & $0.005(0.005)$ & $0.019(0.019)$ & -0.012 & -0.012 & $-0.009(-0.008)$ & $0.005(0.001)$ \\
\hline 3rd Quartile & 0.070 & 0.053 & 0.057 & 0.033 & $1.624(1.796)$ & $2.661(2.661)$ & 0.054 & 0.024 & $0.093(0.101)$ & $0.159(0.137)$ \\
\hline Mean & 0.017 & 0.024 & 0.016 & -0.007 & $0.961(1.003)$ & $1.465(1.465)$ & 0.025 & 0.009 & $0.056(0.060)$ & $0.098(0.088)$ \\
\hline Standard deviation & 0.123 & 0.067 & 0.098 & 0.091 & $1.369(1.387)$ & $1.911(1.911)$ & 0.076 & 0.039 & $0.108(0.111)$ & $0.138(0.134)$ \\
\hline Median & 0.010 & 0.013 & 0.008 & 0.000 & $0.168(0.199)$ & $0.410(0.410)$ & 0.011 & 0.005 & $0.020(0.021)$ & $0.036(0.028)$ \\
\hline $\begin{array}{l}\text { Mean daytime flux } \\
(06: 00-18: 00)\end{array}$ & 0.033 & 0.045 & 0.030 & 0.001 & $1.912(1.978)$ & $2.917(2.917)$ & 0.049 & 0.018 & $0.117(0.120)$ & $0.206(0.207)$ \\
\hline Standard deviation & 0.161 & 0.082 & 0.125 & 0.096 & $1.401(1.383)$ & $1.842(1.842)$ & 0.095 & 0.050 & $0.141(0.129)$ & $0.141(0.144)$ \\
\hline $\begin{array}{l}\text { Median daytime flux } \\
(06: 00-18: 00)\end{array}$ & 0.038 & 0.044 & 0.026 & 0.001 & $1.635(1.790)$ & $2.905(2.905)$ & 0.041 & 0.014 & $0.090(0.099)$ & $0.192(0.164)$ \\
\hline
\end{tabular}

$\overline{\mathrm{LoD}}=\frac{1}{N} \sqrt{\sum_{i=1}^{N} \mathrm{LoD}^{2}}$

Therefore, while the flux time series of methanol, acetaldehyde, acetone, acetic acid, MVK + MACR and MEK are not presented here, the campaign average diurnal fluxes are shown (Fig. 5). As discussed above, 25 min averaged flux files flagged as below the LoD were included in these diurnal averages. Flux files falling below the $0.15 \mathrm{~m} \mathrm{~s}^{-1}$ wind speed threshold were also included to prevent the night-time flux being biased high for depositing compounds. For compounds showing emission, night-time fluxes are close to zero anyway and the application has little influence on the results. Data flagged for non-stationarity were excluded. For a more detailed discussion of the fluxes and mixing ratios of each BVOC and comparison made with other temperate and Mediterranean ecosystems, see the Supplement.

The fluxes of isoprene and monoterpenes calculated using both the PTR-MS and the PTR-ToF-MS instruments are displayed in Fig. 4 and summarized in Table 3. The isoprene fluxes calculated using both instruments show very good correlation $\left(R^{2}=0.91\right.$, slope 1.3 and intercept $\left.0.17 \mathrm{mg} \mathrm{m}^{-2} \mathrm{~h}^{-1}\right)$. The monoterpene fluxes, calculated using $m / z 81$ with the PTR-MS and $m / z 81.070$ with the PTR-ToF-MS show an $R^{2}=0.50$. Three additional mass spectral peaks are observed at $m / z 81$ in the PTR-ToF-MS: $m / z 80.92,80.99$ and 81.03 , however statistically significant fluxes from these peaks could not be calculated using the PTR-ToF-MS. Owing to the lower sensitivity of the PTR-MS at $m / z 81$ and the lower sampling frequency of the disjunct sampling protocol (Rinne and Ammann, 2012), the monoterpene flux calculated using this instrument is significantly noisier than the flux calculated using the PTR-ToF-MS.

PTR-MS and PTR-ToF-MS mass scans were averaged over a 10-day period (14-24 June). A comparison of these mass scans over the range $m / z 33$ to 100 at unit mass resolution is displayed in Fig. 6, with masses reported relative to $m / z 59$ (acetone). A good agreement between the PTR-MS and PTR-ToF-MS is seen for all masses, except for $m / z 33$ for which the PTR-MS gives a significantly higher signal. As both instruments have comparable sensitivities at this mass (11.6 and ca. $10-12$ ncps ppbv $^{-1}$ for the PTR-MS and PTRToF-MS respectively), this discrepancy must be the result of interference from another ion at this mass. $\mathrm{O}^{17} \mathrm{O}^{+}$could in- 

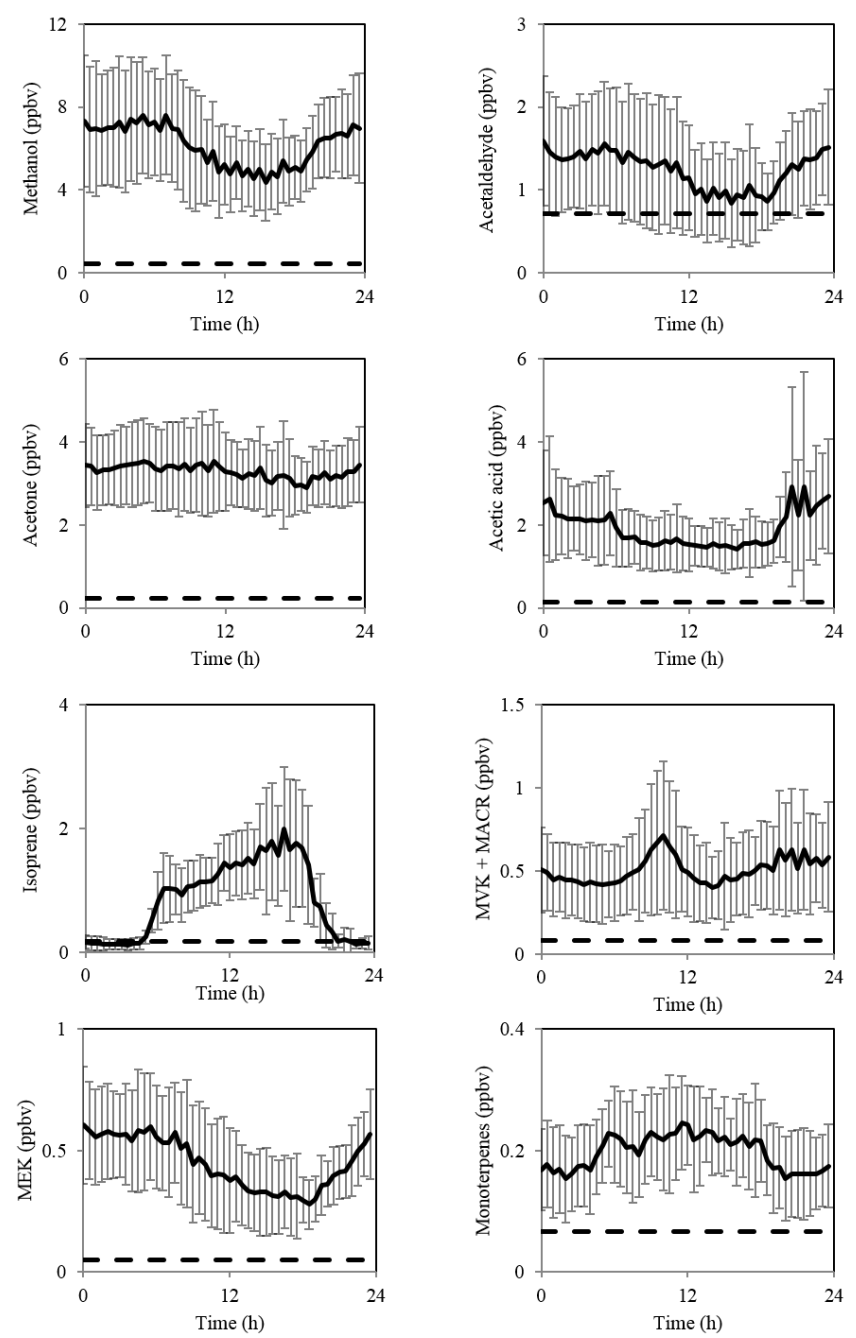

Figure 3. Mean $4 \mathrm{~m}$ above-canopy diurnal mixing ratios by volume of volatile organic compounds measured during the Bosco Fontana field campaign. Error bars represent one standard deviation from the mean and the dashed line denotes limit of detection.

terfere with the methanol signal at $m / z 33$ but as a significant peak is not observed at $m / z, 34\left(\mathrm{O}^{18} \mathrm{O}^{+}\right)$a large contribution from $\mathrm{O}^{17} \mathrm{O}^{+}$to $m / z 33$ is unlikely. This suggests that there is a greater formation of $\mathrm{O}_{2} \mathrm{H}^{+}$in the PTR-MS than in the PTR-ToF-MS under these particular operation parameters. No major mass spectral peaks are observed in one instrument alone, indicating that there is no artefact formation or unexpected loss of chemical species with either instrument. The mass scans show a much cleaner spectrum than was reported by Misztal et al. (2011) above an oil palm plantation in south-east Asia, suggesting an atmosphere dominated by fewer chemical species at higher concentrations.

\subsubsection{BVOC correlations}

Scatter plots were used to investigate the relationship between the measured species. Methanol, acetone and MEK (Fig. 7) all showed a shift in the regression of the BVOCs with increasing temperature with two linear groupings observed, one at lower temperature $\left(\mathrm{ca} .<20^{\circ} \mathrm{C}\right.$ ) and another at higher temperatures (ca. $>20^{\circ} \mathrm{C}$ ). The change in regression could be a result of either different proportions of BVOCs present in high- and low-temperature air masses or by two different sources contributing to the mixing ratios (most likely an atmospheric background and a photochemical source at higher temperatures). It is possible that a second compound could contribute to the nominal mass at higher temperatures but as few compounds have been reported to contribute to $m / z 33$ or 59 , this seems unlikely.

\subsubsection{Short-chain oxygenated BVOCs}

A mean methanol mixing ratio of $6.2 \mathrm{ppbv}$ at $4 \mathrm{~m}$ above the canopy was recorded over the duration of the campaign, making it the dominant BVOC observed at Bosco Fontana. Large mixing ratios of methanol compared with other VOC species (caused by its low photochemical reactivity) have been reported in urban landscapes (Langford et al., 2009). This suggests that the large methanol mixing ratios relative to other VOCs observed $4 \mathrm{~m}$ above the forest at Bosco Fontana may be due to the surrounding agricultural and urban landscape. Mean acetaldehyde, acetone and acetic acid mixing ratios were $3.4,3.2$ and $1.9 \mathrm{ppbv}$ at $4 \mathrm{~m}$ above the canopy respectively. Methanol, acetaldehyde and acetic acid mixing ratios all followed similar diurnal cycles (Fig. 3), with mixing ratios remaining stable through the night before a drop in the morning, probably caused by expansion of the planetary boundary layer after sunrise. Then mixing ratios increased again in the late afternoon as emissions accumulated in a shrinking boundary layer. Acetone mixing ratios remained on average stable throughout the day (Fig. 3). This would suggest a daytime source of acetone offsetting the dilution caused by expansion of the planetary boundary layer. As the flux of acetone, where observed, was very small this source must either be photochemical or situated outside the forest.

The flux of methanol peaked at $0.49 \mathrm{mg} \mathrm{m}^{-2} \mathrm{~h}^{-1}$ with a mean daytime flux of $0.03 \mathrm{mg} \mathrm{m}^{-2} \mathrm{~h}^{-1}$ (Fig. 5). Methanol deposition was observed during the night and mornings followed by a rapid increase in methanol emission in the late morning and peaking in the early afternoon. Bidirectional exchanges of methanol have been reported previously (for example Fares et al., 2012; Karl et al., 2004) with methanol absorption/desorption thought to occur in thin water films within the canopy (Wohlfahrt et al., 2015). The mean morning (06:30-10:30 LT) methanol deposition velocity $\left(V_{\mathrm{d}}\right)$ at the measurement height $\left(z_{\mathrm{m}}\right)$ was calculated using the relationship (Misztal et al., 2011): 

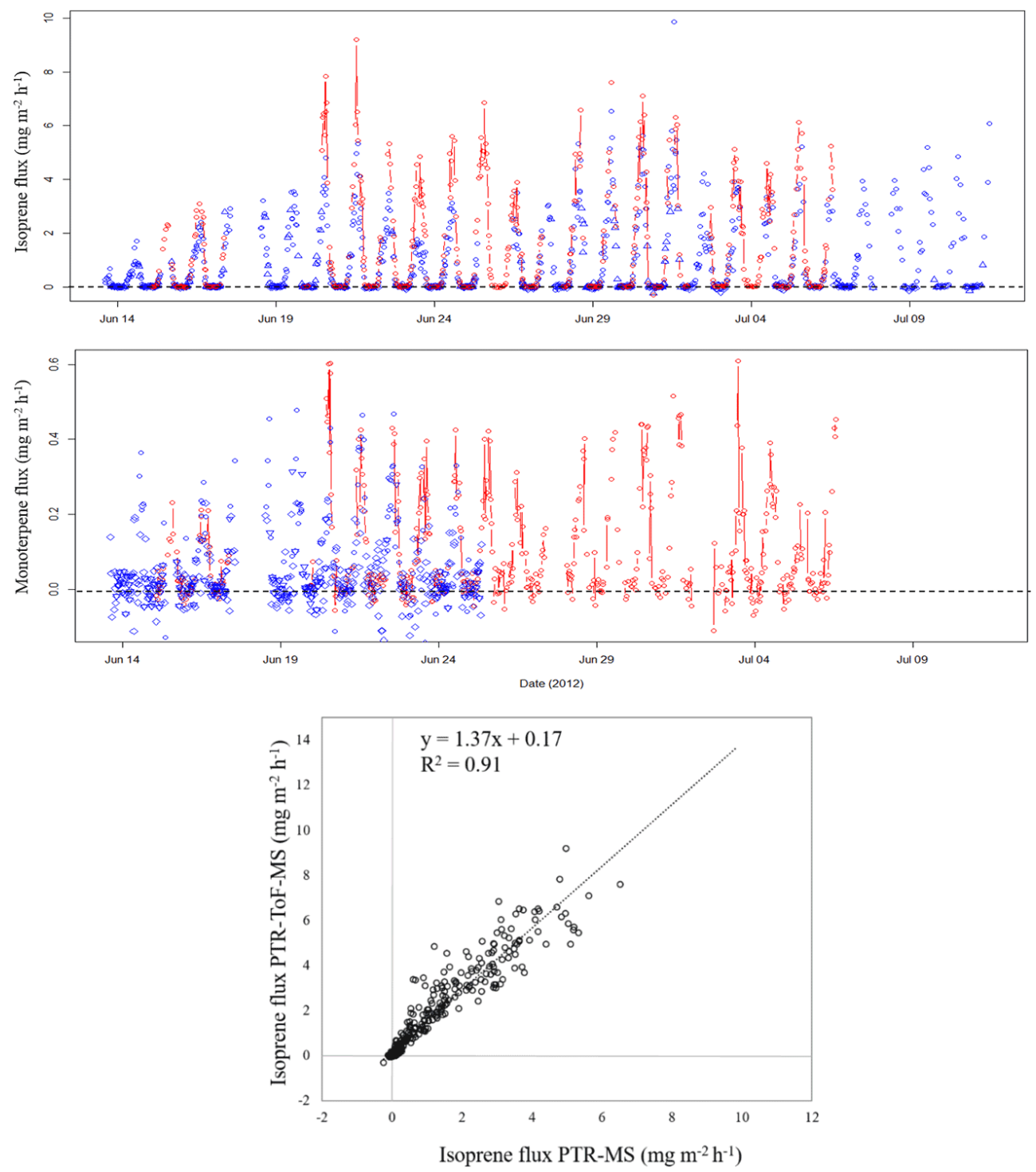

Figure 4. Time series of isoprene (top) and monoterpene (middle) fluxes $\left(\mathrm{mg} \mathrm{m}^{-2} \mathrm{~h}^{-1}\right)$ measured using vDEC. $25 \mathrm{~min}$ averaged flux data from the PTR-MS which passed all tests (blue circles), fell below the $u_{*}$ threshold (triangles) and fell below the LoD (diamonds). Red circles and lines represent PTR-ToF-MS isoprene and monoterpene fluxes with $30 \mathrm{~min}$ averaged flux files failing the stationarity test removed. Bottom: scatter plot showing the relationship between isoprene fluxes calculated using PTR-MS and PTR-ToF-MS.

$V_{\mathrm{d}}\left(z_{\mathrm{m}}\right)=-\frac{F}{\chi\left(z_{\mathrm{m}}\right)}$,

and was found to be $0.31 \mathrm{~cm} \mathrm{~s}^{-1}$. The night-time deposition velocity was lower, $0.02 \mathrm{~cm} \mathrm{~s}^{-1}$, falling at the bottom end of the $0.02-1.0 \mathrm{~cm} \mathrm{~s}^{-1}$ range reported by Wohlfahrt et al. (2015) from a review of eight different Northern Hemisphere sites.

Acetic acid deposition was also observed in the morning, but any emission flux in the afternoon remained below the limit of detection, even if aggregated into mean diurnal cycles. The mean diurnal acetaldehyde flux is shown in Fig. 5. The flux increased from below the detection limit in late morning to a peak in the early afternoon before dropping again towards zero at night. The flux peaked at $0.44 \mathrm{mg} \mathrm{m}^{-2} \mathrm{~h}^{-1}$ on 29 June and the campaign mean daytime flux was $0.06 \mathrm{mg} \mathrm{m}^{-2} \mathrm{~h}^{-1}$. As can be seen in Fig. 5, the acetone flux remained below the limit of detection for most of the day with a small positive flux observed in the late afternoon.

\subsubsection{MVK + MACR and MEK}

MVK and MACR are the main products formed following the first stage of isoprene oxidation in the atmosphere (Atkinson and Arey, 2003), accounting for ca. $80 \%$ of the carbon. 

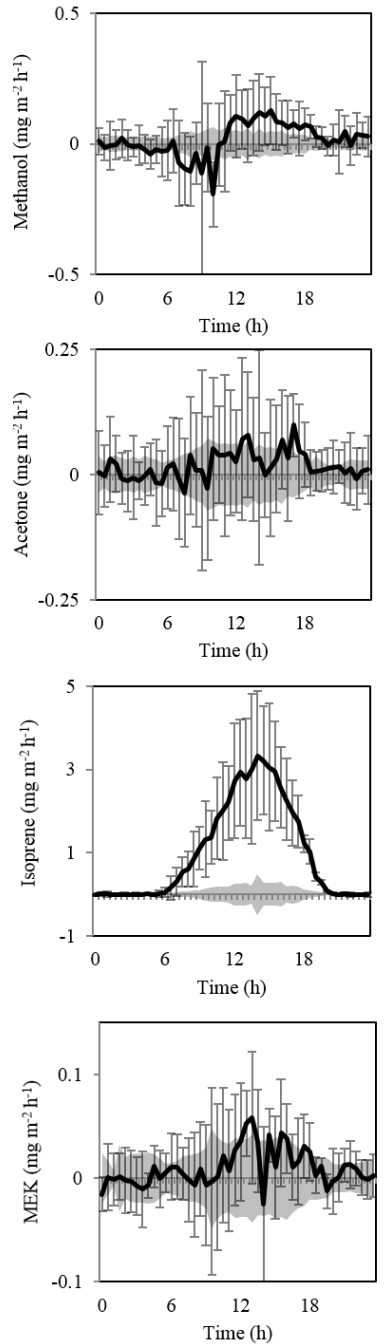
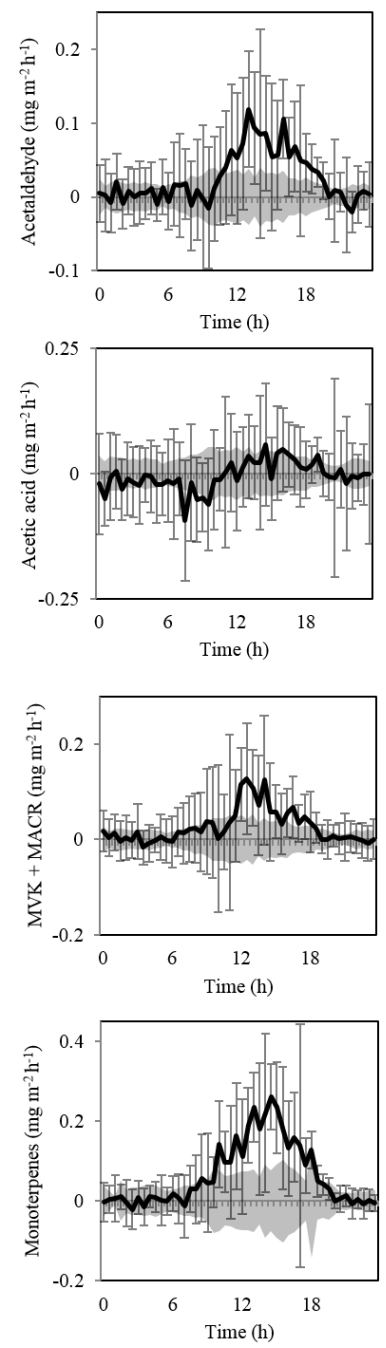

Figure 5. Mean diurnal fluxes of volatile organic compounds measured using vDEC. Shaded area represents the limit of detection of the averaged data, and error bars represent one standard deviation between days from the mean.

MACR can also be directly produced within plants as a byproduct in the production of cyanogenic glycosides (Fall, 2003), and experimental observation demonstrated that emission of MVK and MACR increase with temperature stress (Jardine et al., 2012). The midday (10:00-15:00 LT) mixing ratios of MVK + MACR at $4 \mathrm{~m}$ above the canopy showed a positive correlation with those of isoprene $\left(R^{2}=0.49\right)$, suggesting that the oxidation of isoprene was responsible for the formation of MVK and MACR.

The production of MVK and MACR from isoprene at the Bosco Fontana site has been modelled by Schallhart et al. (2016), who estimated that 4-27\% of the MVK + MACR flux was formed from isoprene oxidization products. MVK and MACR mixing ratios recorded at $4 \mathrm{~m}$ above the canopy (Fig. 3) increase in the morning as isoprene concentrations rise, before boundary layer expansion causes them to drop in the middle of the day. The mixing ratios then increase again in the evening as the boundary layer contracts. The flux of MVK + MACR (Fig. 5) peaked in the early afternoon with a mean daytime flux of $0.05 \mathrm{mg} \mathrm{m}^{-2} \mathrm{~h}^{-1}$. This flux is comparable to the 0.03 and $0.08 \mathrm{mg} \mathrm{m}^{-2} \mathrm{~h}^{-1}$ observed by Kalogridis et al. (2014) and Spirig et al. (2005) over European oak and mixed forests.

MEK may be directly emitted by plants (Fall, 2003) or formed photochemically (Luecken et al., 2012). MEK mixing ratios $4 \mathrm{~m}$ above the forest canopy remained stable through the night at ca. $0.6 \mathrm{ppbv}$ before dropping in the morning, probably caused by expansion of the planetary boundary layer, to ca. $0.3 \mathrm{ppbv}$ and rising again in the evening (Fig. 3). A plot of the mixing ratios of MEK against those of acetone reveals a bimodal distribution suggesting two distinct sinks or sources (Fig. 7), the first occurring at lower temperatures (ca. $12-20^{\circ} \mathrm{C}$ ) with a MEK to acetone ratio of ca. 0.17 and the second at higher temperatures $\left(\mathrm{ca} .20-34^{\circ} \mathrm{C}\right.$ ) with a MEK to acetone ratio of ca. 0.06. A relationship between acetone and MEK has been reported by Riemer et al. (1998), who observed an MEK to acetone ratio of 0.07 at temperatures between 20 and $37^{\circ} \mathrm{C}$. This compares well with the observations at Bosco Fontana. This trend was not observed when data were coloured by PAR, indicating that the bimodal distribution is not driven by the faster rate of reaction of MEK than of acetone with $\mathrm{OH}$. A low MEK emission flux was observed in the afternoon with a mean daytime flux of $0.02 \mathrm{mg} \mathrm{m}^{-2} \mathrm{~h}^{-1}$.

\subsubsection{Isoprene and monoterpenes}

Isoprene mixing ratios $4 \mathrm{~m}$ above the canopy began to rise in the mid-morning from a night-time zero, peaking in the late afternoon at ca. 2 ppbv before falling again to zero in the late evening (Fig. 3). Isoprene fluxes were not observed at night, but increased in the morning to a peak in the mid-afternoon before dropping to zero again in the evening (Fig. 5) with a mean daytime flux of $1.9 \mathrm{mg} \mathrm{m}^{-2} \mathrm{~h}^{-1}$.

Isoprene fluxes correlated with leaf temperature (estimated using a method based on that described by Nemitz et al. (2009) and explained in more detail in the Supplement, $R^{2}=0.73$ for an exponential fit), PAR $\left(R^{2}=0.75\right.$ for an exponential fit) and sensible heat flux $(\mathrm{H})\left(R^{2}=0.67\right)$. The relationship between isoprene fluxes and mixing ratios, temperature and PAR is displayed in Fig. 8. Table 4 compares isoprene flux measurements with the fluxes recorded during other field campaigns in the Mediterranean region and the isoprene emission factor under basal conditions. As would be expected, the flux of isoprene is shown to be highly dependent on ecosystem type. The fluxes observed during this measurement period, when normalized to standard conditions, were lower than those observed over woodland dominated by isoprene-emitting oak species (Baghi et al., 2012; Kalogridis et al., 2014) due to the lower proportion of isoprene-emitting 


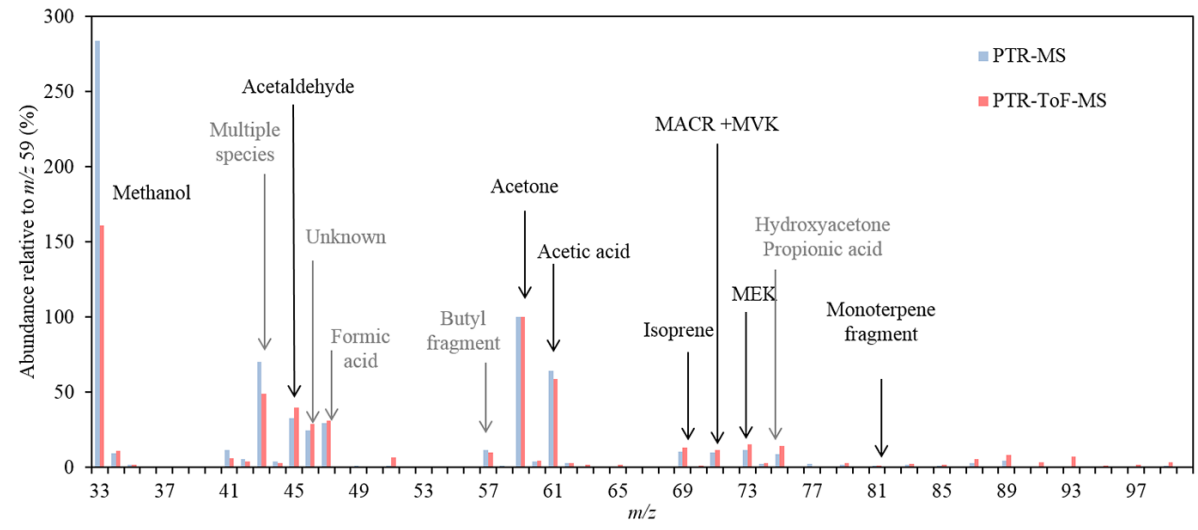

Figure 6. Comparison of PTR-MS (blue) and PTR-ToF-MS (red) mass scans relative to $\mathrm{m} / \mathrm{z} 59$ at unit mass resolution averaged between 14 and 24 June. Compounds recorded in flux mode using the PTR-MS are presented in black with compounds tentatively identified in grey.
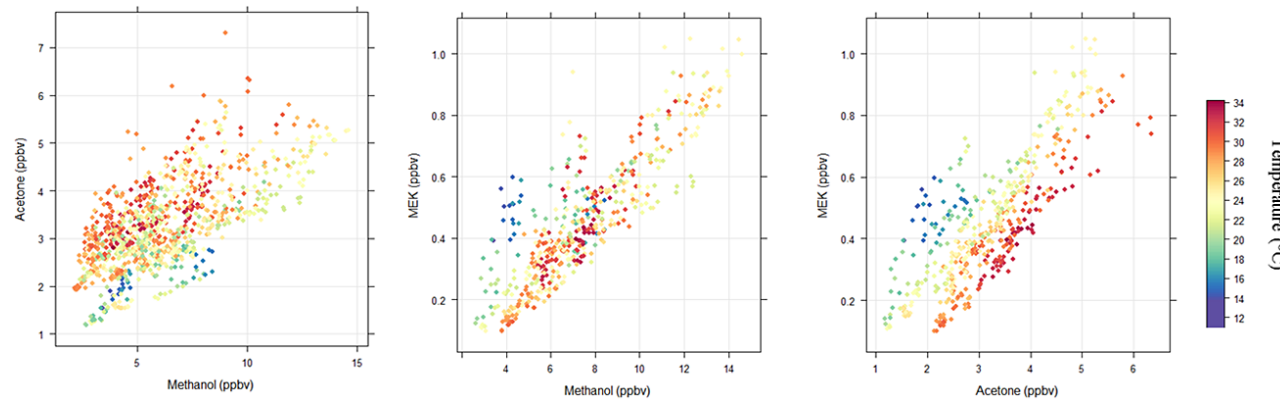

Figure 7. Scatter plots displaying the relationship between the mixing ratios by volume of methanol, acetone and MEK measured $4 \mathrm{~m}$ above the canopy, coloured by temperature.

species in the canopy but closer in magnitude to that observed over a mixed pine and oak forest (Fares et al., 2013).

The campaign mean monoterpene mixing ratio $4 \mathrm{~m}$ above the canopy was $0.2 \mathrm{ppbv}$. The diurnal profile (Fig. 3) shows a night-time mixing ratio of ca. $0.18 \mathrm{ppbv}$, which increases to ca. $0.21 \mathrm{ppbv}$ in the morning, remaining stable through the day and dropping again to ca. $0.18 \mathrm{ppbv}$ at night. The monoterpene flux (Fig. 5) peaked in the early afternoon with a campaign mean midday flux of $0.12 \mathrm{mg} \mathrm{m}^{-2} \mathrm{~h}^{-1}$. Monoterpene mixing ratios were not significantly correlated with leaf-surface temperature or with PAR $\left(R^{2}=0.11\right.$ and 0.12 respectively). However, the flux displayed a correlation with both leaf-surface temperature and PAR $\left(R^{2}=0.44\right.$ and 0.39 respectively).

\subsection{Impacts on air quality}

The forest at Bosco Fontana provides a large source of BVOCs in a region of predominantly agricultural and urban land use. The oxidation of BVOCs leads to the formation of low-volatility organic compounds which in turn contribute to SOA (Ehn et al., 2014). The importance of individual BVOC species to SOA formation is, however, variable, with large and cyclic compounds likely to contribute more to SOA formation (Hallquist et al., 2009). Monoterpenes are known to contribute significantly to SOA formation. The principal monoterpene species observed during this campaign were $\alpha$-pinene, $\beta$-pinene, sabinene and limonene (Table 5). Following ozonolysis of $\alpha$-pinene and $\beta$-pinene, Lee et al. (2006) observed aerosol yields of 41 and $17 \%$. Aerosol yields of 41 and $17 \%$ were assigned to limonene and sabinene, due to the placement of $C-C$ double bonds within/external to the cyclic structure. The average aerosol yield from monoterpene ozonolysis during the campaign may then be calculated based on the proportion of each compound emitted. This gives a ca. $39 \%$ yield of aerosol, contributing ca. $0.38 \mu \mathrm{g} \mathrm{C} \mathrm{m}^{-3}$ to aerosol (based on the campaign average monoterpene mixing ratio) (0.198 ppbv).

Significant aerosol formation from isoprene has been reported in low $\mathrm{NO}_{x}$ environments (Claeys et al., 2004), however, the high $\mathrm{NO}_{x}$ concentrations at the Bosco Fontana Nature Reserve (Finco et al., 2016) make a significant contribution to SOA from isoprene unlikely.

In the presence of $\mathrm{NO}_{x}$, BVOCs can facilitate the formation of tropospheric ozone. As the potential for photochemical ozone formation is five times greater from isoprene than from VOCs emitted following urban anthropogenic activity 
Table 4. Non-exhaustive summary of isoprene fluxes recorded in the Mediterranean region and the isoprene emission factor under basal conditions (temperature: $30^{\circ} \mathrm{C}$ and PAR: $1000 \mu \mathrm{mol} \mathrm{m}^{-2} \mathrm{~s}^{-1}$ ).

\begin{tabular}{|c|c|c|c|c|c|}
\hline Ecosystem & Dominant species & Season & $\begin{array}{l}\text { Mean daytime } \\
\text { isoprene flux } \\
\left(\mathrm{mg} \mathrm{m}^{-2} \mathrm{~h}^{-1}\right)\end{array}$ & $\begin{array}{l}\text { Isoprene emission } \\
\text { factor under basal } \\
\text { conditions } \\
\left(\mathrm{mg} \mathrm{m}^{-2} \mathrm{~h}^{-1}\right)\end{array}$ & Reference \\
\hline $\begin{array}{l}\text { Mixed oak and } \\
\text { hornbeam forest }\end{array}$ & $\begin{array}{l}\text { Carpinus betulus } \\
\text { Quercus robur }\end{array}$ & Summer & 2.6 & 1.7 & This study \\
\hline Oak forest & Quercus pubescens & Spring & 2.8 & 7.4 & Kalogridis et al. (2014) \\
\hline Oak forest & Quercus pubescens & Summer & $5.4-10.1$ & 5.4 & Baghi et al. (2012) \\
\hline $\begin{array}{l}\text { Mixed oak and } \\
\text { pine forest }\end{array}$ & $\begin{array}{l}\text { Pinus pinea } \\
\text { Quercus ilex } \\
\text { Quercus suber }\end{array}$ & Autumn & ca. 0.13 & 0.61 & Fares et al. (2013) \\
\hline
\end{tabular}

Table 5. Leaf-level isoprene and monoterpene emission $\left(\mathrm{mg} \mathrm{m}^{-2} \mathrm{~h}^{-1}\right)$ recorded using GC-MS from single leaves under basal conditions (temperature: $30^{\circ} \mathrm{C}$ and PAR: $1000 \mu \mathrm{mol} \mathrm{m}^{-2} \mathrm{~s}^{-1}$ ). ND signifies not detected.

\begin{tabular}{|c|c|c|c|c|c|c|}
\hline Tree species & $\begin{array}{l}\text { isoprene flux } \\
\text { (standard error) }\end{array}$ & $\begin{array}{l}\alpha \text {-pinene flux } \\
\text { (standard error) }\end{array}$ & $\begin{array}{l}\text { sabinene flux } \\
\text { (standard error) }\end{array}$ & $\begin{array}{l}\beta \text {-pinene flux } \\
\text { (standard error) }\end{array}$ & $\begin{array}{l}\text { limonene flux } \\
\text { (standard error) }\end{array}$ & $\begin{array}{l}\text { sum monoter- } \\
\text { pene flux }\end{array}$ \\
\hline Carpinus betulus & $\begin{array}{l}2.25 \times 10^{-3} \\
\left(1.50 \times 10^{-3}\right)\end{array}$ & $\begin{array}{l}1.07 \times 10^{-2} \\
\left(6.00 \times 10^{-3}\right)\end{array}$ & $\begin{array}{l}1.81 \times 10^{-2} \\
\left(1.36 \times 10^{-2}\right)\end{array}$ & $\begin{array}{l}5.14 \times 10^{-2} \\
\left(1.23 \times 10^{-2}\right)\end{array}$ & $\begin{array}{l}5.83 \times 10^{-1} \\
\left(2.36 \times 10^{-1}\right)\end{array}$ & $6.63 \times 10^{-1}$ \\
\hline Quercus robur & $\begin{array}{l}2.39 \times 10^{0} \\
\left(6.12 \times 10^{-1}\right)\end{array}$ & $\begin{array}{l}2.81 \times 10^{-2} \\
\left(1.45 \times 10^{-2}\right)\end{array}$ & ND & $\begin{array}{l}4.70 \times 10^{-3} \\
\left(3.08 \times 10^{-3}\right)\end{array}$ & $\begin{array}{l}2.16 \times 10^{-1} \\
\left(6.49 \times 10^{-2}\right)\end{array}$ & $2.49 \times 10^{-1}$ \\
\hline Quercus rubra & $\begin{array}{l}9.14 \times 10^{-1} \\
\left(2.02 \times 10^{-1}\right)\end{array}$ & ND & ND & $\begin{array}{l}7.95 \times 10^{-3} \\
\left(2.22 \times 10^{-3}\right)\end{array}$ & $\begin{array}{l}2.34 \times 10^{-2} \\
\left(7.11 \times 10^{-3}\right)\end{array}$ & $3.13 \times 10^{-2}$ \\
\hline Corylus avellana & $\begin{array}{l}4.97 \times 10^{-4} \\
\left(3.93 \times 10^{-4}\right)\end{array}$ & $\begin{array}{l}1.30 \times 10^{-2} \\
\left(8.00 \times 10^{-3}\right)\end{array}$ & ND & $\begin{array}{l}2.08 \times 10^{-2} \\
\left(4.80 \times 10^{-3}\right)\end{array}$ & $\begin{array}{l}7.57 \times 10^{-1} \\
\left(4.15 \times 10^{-1}\right)\end{array}$ & $7.90 \times 10^{-1}$ \\
\hline Acer campestre & $\begin{array}{l}4.40 \times 10^{-4} \\
\left(3.11 \times 10^{-4}\right)\end{array}$ & $\begin{array}{l}5.14 \times 10^{-2} \\
\left(2.95 \times 10^{-2}\right)\end{array}$ & ND & $\begin{array}{l}2.27 \times 10^{-1} \\
\left(3.54 \times 10^{-2}\right)\end{array}$ & $\begin{array}{l}1.07 \times 10^{-1} \\
\left(1.41 \times 10^{-2}\right)\end{array}$ & $3.85 \times 10^{-1}$ \\
\hline Sambucus nigra & $\begin{array}{l}4.09 \times 10^{-3} \\
\left(3.66 \times 10^{-3}\right)\end{array}$ & ND & ND & $\begin{array}{l}9.67 \times 10^{-3} \\
\left(2.69 \times 10^{-3}\right)\end{array}$ & $\begin{array}{l}2.49 \times 10^{-1} \\
\left(1.41 \times 10^{-1}\right)\end{array}$ & $2.59 \times 10^{-1}$ \\
\hline Cornus sanguinea & $\begin{array}{l}4.00 \times 10^{-1} \\
\left(4.00 \times 10^{-1}\right)\end{array}$ & $\begin{array}{l}1.11 \times 10^{-3} \\
\left(1.11 \times 10^{-3}\right)\end{array}$ & ND & $\begin{array}{l}1.95 \times 10^{-2} \\
\left(4.91 \times 10^{-3}\right)\end{array}$ & $\begin{array}{l}2.28 \times 10^{-1} \\
\left(1.73 \times 10^{-1}\right)\end{array}$ & $2.49 \times 10^{-1}$ \\
\hline
\end{tabular}

(Derwent et al., 2007; Hewitt et al., 2009), the high isoprene emission observed here will have a significant impact on tropospheric ozone formation in the high $\mathrm{NO}_{x}$ environment at and downwind of the Bosco Fontana Nature Reserve. The emission of isoprene from the Bosco Fontana reserve, together with other forest fragments and poplar plantations with the Po Valley, is likely to have a significant impact upon tropospheric ozone concentrations in the region.

\subsection{Calculation of isoprene and monoterpene canopy-level emission factors}

Although other approaches do exist, isoprene fluxes are widely modelled using MEGAN (Guenther et al., 2006). MEGAN calculates isoprene fluxes based on the product of an emission activity factor $(\gamma)$, a canopy loss and production factor $(\rho)$ and a canopy emission factor $(\varepsilon)$. Therefore, plotting isoprene flux against $\gamma \times \rho$ enables the calculation of a canopy-specific isoprene emission factor (Fig. 9), giving value of $1.68 \mathrm{mg} \mathrm{m}^{-2} \mathrm{~h}^{-1}$ at standard conditions $\left(1000 \mu \mathrm{mol} \mathrm{m}{ }^{-2} \mathrm{~s}^{-1}\right.$ PAR and $\left.303 \mathrm{~K}\right)$ for the campaign period. For the purpose of this work, $\rho$ was assumed to be 0.96. This is supported by Schallhart et al. (2016), who found that between 3 and $5 \%$ of isoprene emissions were lost within the canopy at the Bosco Fontana reserve. The emission activity factor, $\gamma$, was calculated using the algorithms described by Guenther et al. (2006). Radiative transfer through the canopy was modelled using the model applied by Müller et al. (2008). This model was based on that of Goudriaan and van Laar (1994) and ambient temperature was recorded $4 \mathrm{~m}$ above the canopy. The standard light and temperature conditions for MEGAN canopy-scale emission factors are $\sim 1500 \mu \mathrm{mol} \mathrm{m}^{-2} \mathrm{~s}^{-1}$ and $303 \mathrm{~K}$ (Guenther et al., 2006). In order to enable direct comparison between the GC-MS data and literature emission factors, the factor which sets the emission activity to unity at standard conditions $\left(C_{\mathrm{CE}}\right)$ was increased to 1.42 . This gave standard light 

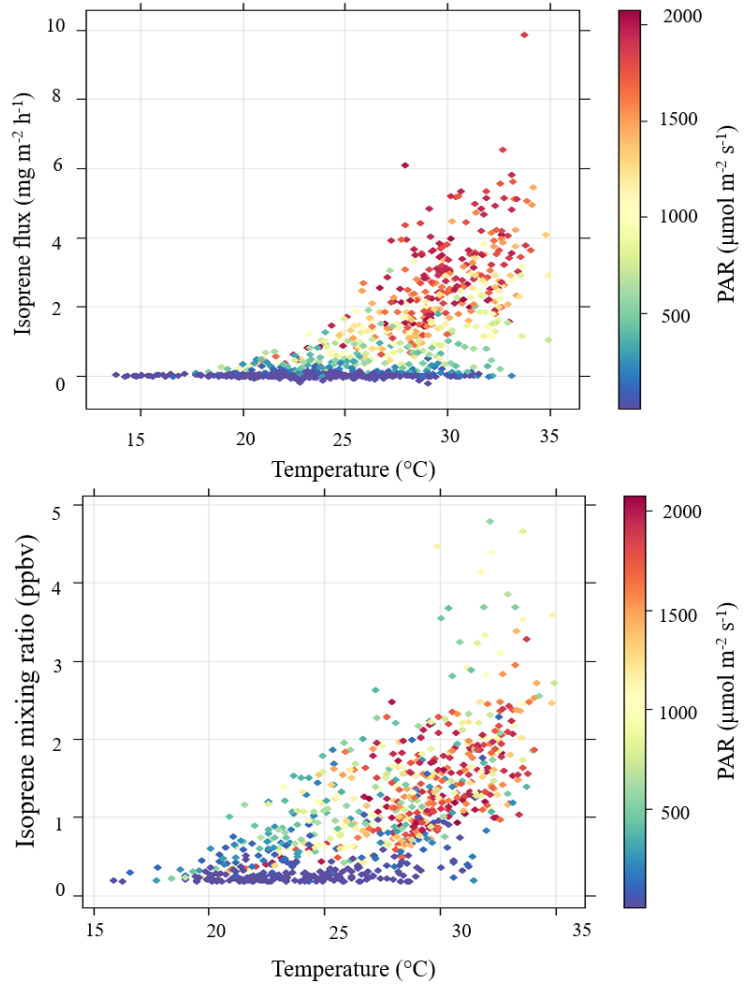

Figure 8. The relationship between temperature $\left({ }^{\circ} \mathrm{C}\right)$ and isoprene fluxes $\left(\mathrm{mg} \mathrm{m}^{-2} \mathrm{~h}^{-1}\right)$ and mixing ratios (ppbv), coloured according to the magnitude of photosynthetically active radiation $\left(\mu \mathrm{mol} \mathrm{m} \mathrm{s}^{-1} \mathrm{~s}^{-1}\right)$.

and temperature conditions of $1000 \mu \mathrm{mol} \mathrm{m} \mathrm{m}^{-2} \mathrm{~s}^{-1}$ and $303 \mathrm{~K}$ respectively.

The emission factor is lower than those calculated by Kalogridis et al. (2014) and Baghi et al. (2012) from oak (Quercus pubescens)-dominated forests in southern France (7.4 and $5.4 \mathrm{mg} \mathrm{m}^{-2} \mathrm{~h}^{-1}$ respectively). However, this is to be expected, owing to the high proportion of low or nonisoprene-emitting species such as Carpinus betulus, Corylus avellana, Sambucus nigra and Acer campestre present in the forest at Bosco Fontana.

Monoterpene emission from plants may take the form of pool or de novo emission. Emission from stored pools is temperature controlled whereas de novo is driven by photosynthesis and is therefore controlled by light as well as temperature (Ghirardo et al., 2010). Emission from stored pools was modelled using the monoterpene-temperature relationship described by Guenther et al. (1995), this model correlated well with the observed monoterpene flux (PTRToF-MS) giving $R^{2}$ value of 0.55 . In order to assess the effect of light on monoterpene emission, the residual values from the temperature-only model were plotted against PAR (Fig. 10). The residuals displayed a correlation with PAR $\left(R^{2}=0.45\right)$, indicating that light as well as temperature have a significant impact on monoterpene emissions

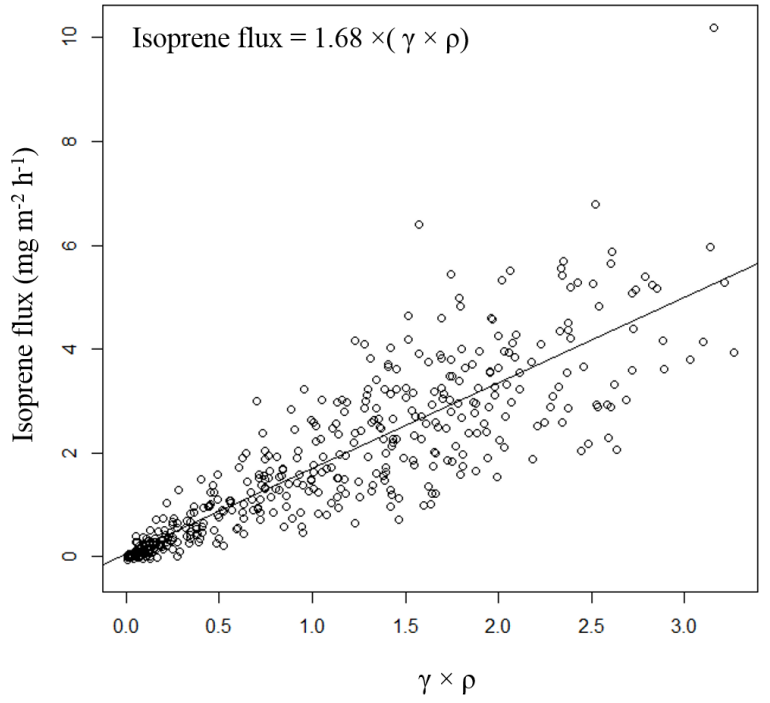

Figure 9. Measured isoprene fluxes against the product of $\gamma$ (emission activity factor, itself the product of the temperature, light and leaf area index activity factors) and $\rho$ (the canopy loss and production factor).

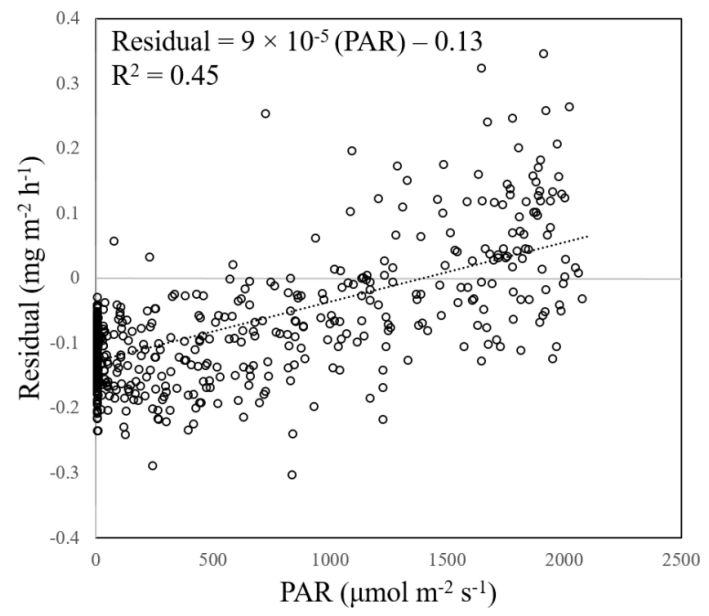

Figure 10. Plot of the residual values from the temperature-only monoterpene emission model against PAR, demonstrating that light as well as temperature has a significant impact on monoterpene emissions.

from the forest canopy and therefore a significant proportion of monoterpene emission represent de novo emission. However, in order to accurately assess the contribution of pool and de novo emissions to the canopy-scale monoterpene flux, a species-specific leaf-level investigation would be required. A monoterpene canopy emission factor calculated using the MEGAN algorithms, which only simulate de novo emission, was found to be $0.14 \mathrm{mg} \mathrm{m}^{-2} \mathrm{~h}^{-1}$. 


\subsection{Speciated bottom-up isoprene and monoterpene flux estimates derived from leaf-level measurements}

Tree-species distribution data combined with information on leaf-level isoprene and monoterpene emission rates and meteorological data were used to produce a bottom-up estimate of the total canopy-level flux. Tree species distribution data were obtained from Dalponte et al. (2007), this tree species distribution map reveals an uneven distribution of isopreneemitting species within the forest canopy, with the two main isoprene-emitting species $(Q$. robur and $Q$. rubra) concentrated in the south of the forest.

Leaf-level isoprene and monoterpene emissions from the dominant tree species were recorded using GC-MS (Table 5). Together these species represent $76.6 \%$ of the total vegetation cover. Isoprene emission was dominated by $Q$. robur and $Q$. rubra with $C$. avellana and C. betulus as the highest monoterpene-emitting species. The isoprene emission recorded for both oak species was lower than that previously reported (Karl et al., 2009; Keenan et al., 2009). For species where GC-MS data were not available, literature values were used. Leaf-level emission factors for minor species for which no GC-MS measurements were made were taken from Karl et al. (2009) with the exception Rubus sp. (Owen et al., 2001) and Acer negundo and Morussp. (Benjamin et al., 1996). Emission factors taken from the literature were converted from $\mu \mathrm{gg}_{\text {DW }}^{-1} \mathrm{~h}^{-1}$ to $\mathrm{mg} \mathrm{m}^{-2} \mathrm{~h}^{-1}$ using the mean leaf mass to area ratio, $115 \mathrm{~g}_{\mathrm{DW} \mathrm{m}}{ }^{-2}$, reported by $\mathrm{Ni}-$ inemets (1999) from a study of ca. 600 species. The leaf-level emission data were then scaled up to a canopy level using the MEGAN algorithms (Guenther et al., 2006) and incorporated measured PAR and temperature values averaged over $30 \mathrm{~min}$ as well as a single-sided leaf-area index (LAI, $\mathrm{m}^{2} \mathrm{~m}^{-2}$ ) of 5.5.

The hyperspectral/lidar data of Dalponte et al. (2007) were remapped onto a grid centred on the measurement site, with a resolution of $5 \mathrm{~m}^{2}$, providing fractional ground cover by each of the 20 tree species within each grid cell. The contribution of each grid cell to each 25 min flux measurement was then calculated at $5 \mathrm{~m}^{2}$ resolution using a high- resolution 2D footprint model based on Kormann and Meixner (2001) similar to that described by Neftel et al. (2008). Finally, the MEGAN algorithm was applied to all plant species using the 25 min meteorology. The information was combined to provide a bottom-up estimate of the flux that the canopyscale measurements should have detected, based on the leaflevel data. This footprint and species-dependent bottom-up flux estimate showed significantly better agreement with the measured isoprene flux $\left(R^{2}=0.75\right.$, slope $\left.=0.56\right)$ than was observed when the canopy-scale isoprene emission factor calculated above was used $\left(R^{2}=0.65\right.$, slope $\left.=0.76\right)$. This demonstrates the large effect an uneven distribution of isoprene sources can have on the above-canopy flux, even within what appears to be a uniform canopy, as well as the bene- fit for accounting for spatial species distributions in uniform vegetation canopies.

However, despite capturing the shape of the flux time series, the bottom-up flux underestimated the magnitude of the flux, capturing $56 \%$ of the isoprene flux as measured by vDEC. This could in part be caused by changes in vegetation cover between the tree distribution mapping in 2008 and the flux measurements in 2012. There are anecdotal reports that Populus sp. coverage has increased in the understory vegetation but it is unlikely that, despite their high rates of growth, the Populus coverage changed significantly in the four years between mapping and this campaign. Since 2008, the non-native $Q$. rubra is gradually being removed from the forest. However, this does not explain the discrepancy between the vDEC isoprene flux measurements and the bottomup flux estimate as the reduction in the number of $Q$. rubra trees should have decreased the flux. Whilst the hyperspectral/lidar tree-species data for this site provide a unique opportunity for comparing the canopy-scale measurements with a detailed bottom-up estimate, the hyperspectral/lidar data only provide information on projected tree species area as seen from above, whilst the flux is regulated by leaf mass and its exposure to radiation. Thus there are uncertainties in the ability of the hyperspectral/lidar to detect understorey vegetation and a single conversion factor was used between projected tree area and leaf mass. However, understorey vegetation is less exposed to sunlight, reducing its emission. Indeed, the main reason for the underestimate of isoprene flux is probably that the leaf-level isoprene emission rate recorded from the leaves sampled at ground level (albeit taken at the edge of sun exposed clearings) are not representative of those at the canopy top. Substituting the measured $Q$. robur and Q. rubra emission factors with those reported by Karl et al. (2009) caused the bottom-up estimate to give $130 \%$ of the measured flux and improved the correlation between bottomup estimates and canopy-scale measurements further.

The speciated monoterpene flux (calculated using GCMS data and literature values for species where GC-MS data were not available) also showed good agreement with the above-canopy flux $\left(R^{2}=0.72\right)$ and captured $57 \%$ of the flux. The discrepancy between the magnitude of the speciated monoterpene flux and the above-canopy flux could be partially explained by loss of monoterpenes through within canopy oxidation. Schallhart et al. (2016) investigated the flux loss due to chemical degradation using measured concentrations of ozone and $\mathrm{NO}_{2}$, together with calculated $\mathrm{OH}$ and $\mathrm{NO}_{3}$ concentrations. They found that $5-20 \%$ of the monoterpene flux was lost via degradation (in comparison just $3-5 \%$ of the isoprene flux was lost). The bottom-up monoterpene flux estimate may also have been affected by the changes to the tree species distribution in the four years between mapping and this campaign, as discussed above, and by deposition of monoterpenes within the forest canopy.

The contribution of different species to the isoprene and monoterpene fluxes over the course of an example day is 


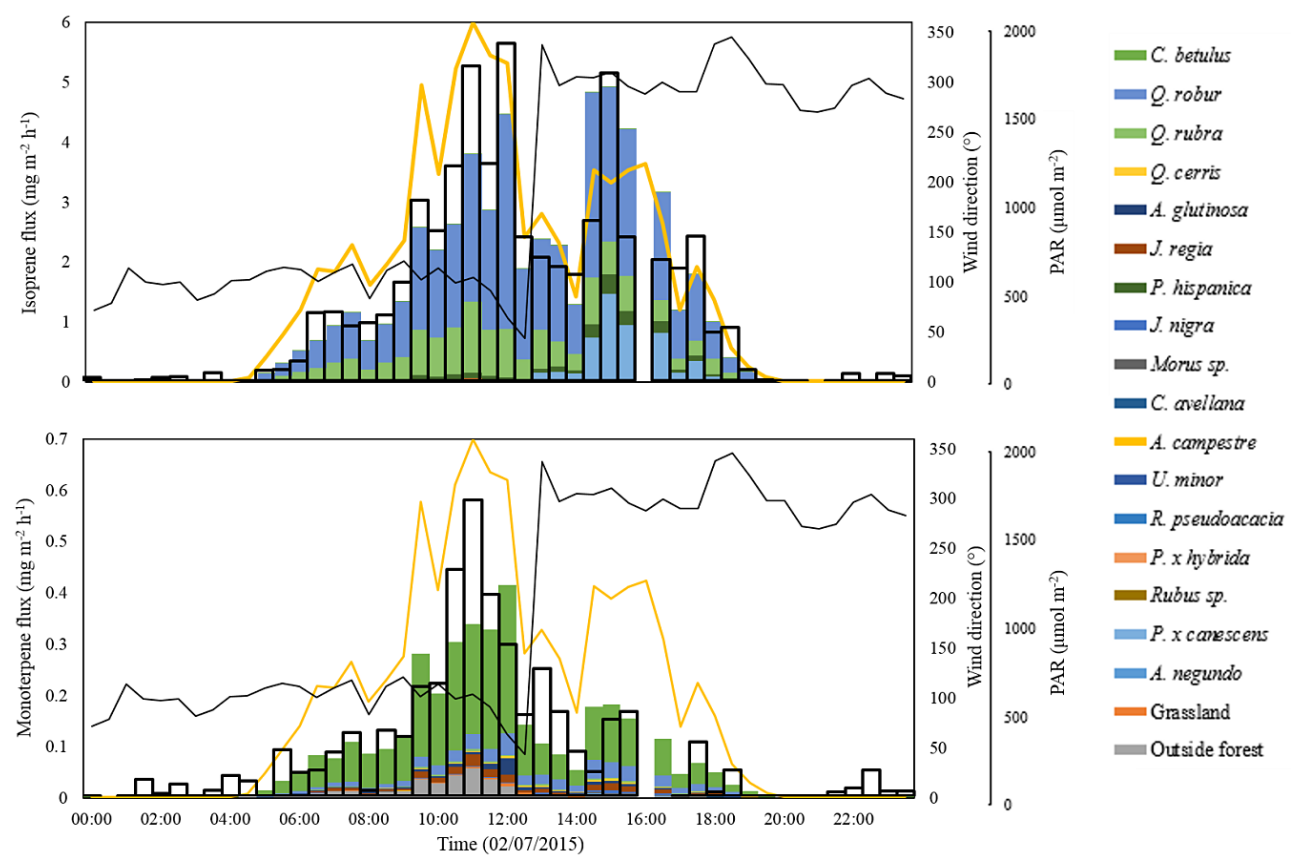

Figure 11. The contribution of individual tree species to the speciated isoprene and monoterpene flux on the 2 July 2012 . PAR is displayed as a yellow line, wind direction as a black line and the flux recorded using the PTR-MS as bold black bars.

Table 6. Species-specific isoprene and monoterpene emission factors (for a standard temperature of $30^{\circ} \mathrm{C}$ and a PAR value of $1000 \mu \mathrm{mol} \mathrm{m}^{-2} \mathrm{~s}^{-1}$ ). Values derived from optimizing the leaf-level emission factors to give the best fit with the measured above-canopy isoprene and monoterpene fluxes within the constraints displayed.

\begin{tabular}{|c|c|c|c|c|}
\hline Species & $\begin{array}{r}\text { Isoprene } \\
\text { emission factor } \\
\left(\mathrm{mg} \mathrm{m}^{-2} \mathrm{~h}^{-1}\right)\end{array}$ & $\begin{array}{r}\text { Isoprene } \\
\text { constraint } \\
\left(\mathrm{mg} \mathrm{m}^{-2} \mathrm{~h}^{-1}\right)\end{array}$ & $\begin{array}{r}\text { Monoterpene } \\
\text { emission factor } \\
\left(\mathrm{mg} \mathrm{m}^{-2} \mathrm{~h}^{-1}\right)\end{array}$ & $\begin{array}{r}\text { Monoterpene } \\
\text { constraint } \\
\left(\mathrm{mg} \mathrm{m}^{-2} \mathrm{~h}^{-1}\right)\end{array}$ \\
\hline Acer campestre & 0.00 & $<1.0$ & 0.15 & $<0.50$ \\
\hline Acer negundo & 0.00 & $<1.0$ & 0.33 & $<0.64$ \\
\hline Alnus glutinosa & 0.01 & $<1.0$ & 0.22 & $<0.50$ \\
\hline Carpinus betulus & 0.00 & $<1.0$ & 0.57 & $<0.63$ \\
\hline Corylus avellana & 0.00 & $<1.0$ & 0.23 & $<0.50$ \\
\hline Fraxinus angustifolia & 0.00 & $<1.0$ & 0.00 & $<0.50$ \\
\hline Juglans nigra & 0.00 & $<1.0$ & 0.12 & $<0.50$ \\
\hline Juglans regia & 0.36 & $<1.0$ & 0.15 & $<0.50$ \\
\hline Morus sp. & 0.00 & $<1.0$ & 0.19 & $<0.50$ \\
\hline Platanus hispanica & 2.97 & $<4.4$ & 0.50 & $<0.50$ \\
\hline Populus $\times$ canescens & 10.66 & $<16.1$ & 0.29 & $<0.50$ \\
\hline Populus $\times$ hybrida & 8.06 & $<16.1$ & 0.00 & $<0.50$ \\
\hline Prunus avium & 0.00 & $<1.0$ & 0.01 & $<0.50$ \\
\hline Quercus cerris & 0.02 & $<1.0$ & 0.07 & $<0.50$ \\
\hline Quercus robur & 7.46 & $<16.1$ & 0.19 & $<0.50$ \\
\hline Quercus rubra & 1.38 & $<8.1$ & 0.02 & $<0.50$ \\
\hline Robinia pseudoacacia & 1.38 & $<2.8$ & 0.01 & $<0.50$ \\
\hline Rubus sp. & 0.00 & $<1.0$ & 0.01 & $<0.50$ \\
\hline Tilia sp. & 0.00 & $<1.0$ & 0.00 & $<0.50$ \\
\hline Ulmus minor & 0.01 & $<1.0$ & 0.01 & $<0.50$ \\
\hline Grass & 0.06 & $<1.0$ & 0.06 & $<0.15$ \\
\hline Not woodland & 0.06 & $<1.0$ & 0.08 & $<0.15$ \\
\hline Outside forest & 0.06 & $<1.0$ & 0.06 & $<0.50$ \\
\hline
\end{tabular}


shown in Fig. 11. As is shown, the isoprene flux was dominated by $Q$. robur but was sensitive to the species composition within the flux footprint. The change in wind direction around 14:00 LT reduced the contribution of $Q$. rubra to the total flux, with the contribution of Populus $\times$ canescens increasing significantly. The monoterpene flux was predicted to have been dominated by $C$. betulus, the dominant tree species in the canopy at Bosco Fontana. A greater number of tree species contributed to the monoterpene flux, and emissions were therefore much more uniform across the canopy and less affected by changes in wind direction.

The fit between the above-canopy measured isoprene and monoterpene fluxes and the bottom-up flux estimate was improved by optimizing the leaf-level emission factors, within the constraints displayed in Table 6, using $\mathrm{Chi}^{2}$ minimization as implemented by the solver function in Microsoft Excel. Use of the optimized isoprene and monoterpene emission factors gave good correlations with measured fluxes $\left(R^{2}\right.$ values of 0.75 and 0.76 respectively). The optimized isoprene and monoterpene emission factors are presented in Table 6 and show a reasonable agreement with literature values (Karl et al., 2009).

\section{Conclusions}

Direct above-canopy fluxes of methanol, acetaldehyde, acetic acid, isoprene, MVK + MACR, MEK and monoterpenes were calculated using the method of virtual disjunct eddy covariance from mixing ratio data obtained with a PTRMS above a semi-natural mixed oak and hornbeam forest in northern Italy from 13 June to 11 July 2012. Isoprene was the dominant BVOC emitted with a mean daytime flux of $1.91 \mathrm{mg} \mathrm{m}^{-2} \mathrm{~h}^{-1}$. When normalized to standard conditions (temperature of $30^{\circ} \mathrm{C}$, PAR of $1000 \mu \mathrm{mol} \mathrm{m}{ }^{-2} \mathrm{~s}^{-1}$ ) using the MEGAN model (Guenther et al., 2006), a canopy-scale emission factor of $1.68 \mathrm{mg} \mathrm{m}^{-2} \mathrm{~h}^{-1}$ was derived. Mixing ratios of VOCs measured at $4 \mathrm{~m}$ above the forest canopy were dominated by those of methanol, with a campaign mean mixing ratio of 6.2 ppbv.

The isoprene fluxes obtained using the PTR-MS/vDEC system showed good agreement with those obtained using a direct eddy covariance (with mixing ratios by volume measured with a fast response PTR-ToF-MS instrument). Monoterpene fluxes recorded using the PTR-MS were noisier and marginally higher than those recorded using the PTRToF-MS due to a lower sensitivity and, probably, the inclusion of isobaric compounds. Comparison of mass scan data generated using the PTR-MS and PTR-ToF-MS $(\mathrm{m} / \mathrm{z} 33-$ $100)$ showed very good agreement with no significant masses observed in one instrument but not in the other.

Upscaling leaf-level isoprene and monoterpene emissions to the canopy scale, using a high spatial resolution tree species database and a 2-D footprint model, showed significantly better correlation with the measured above-canopy fluxes than was obtained using a canopy-scale emission factor. Leaf-level isoprene emission resulted in an underestimate of the above-canopy isoprene flux and this was assumed to be the result of differences in isoprene emission rates from leaves sampled at ground-level and those at the canopy top.

Overall, the data obtained give confidence in the measurement of biogenic VOC fluxes by the method of virtual disjunct eddy covariance and highlight the importance of using leaf-level emission data from sunlit canopy-top leaves when upscaling leaf-level emission to produce a bottom-up canopy-scale emission estimate.

\section{The Supplement related to this article is available online at doi:10.5194/acp-16-7149-2016-supplement.}

Acknowledgements. W. J. F. Acton would like to thank Alex Guenther for his advice on the use of MEGAN. This work was funded by the EU FP7 grants ÉCLAIRE (grant 282910) and PEGASOS (grant 265148), as well as by a BBSRC/Ionicon Analytik GmbH Industrial CASE studentship awarded to W. J. F. Acton. We acknowledge access to the measurement site provided by the Italian Corpo forestale dello Stato and provision of the site infrastructure by the Catholic University of Italy at Brescia and in particular by Giacomo Gerosa, Angelo Finco and Riccardo Marzuoli.

Edited by: K.-E. Min

\section{References}

Arneth, A., Monson, R. K., Schurgers, G., Niinemets, Ü., and Palmer, P. I.: Why are estimates of global terrestrial isoprene emissions so similar (and why is this not so for monoterpenes)?, Atmos. Chem. Phys., 8, 4605-4620, doi:10.5194/acp-8-46052008, 2008.

Ashmore, M. R.: Assessing the future global impacts of ozone on vegetation, Plant Cell Environ., 28, 949-964, 2005.

Atkinson, R. and Arey, J.: Gas-phase tropospheric chemistry of biogenic volatile organic compounds: a review, Atmos. Environ., 37, 197-219, 2003.

Baghi, R., Durand, P., Jambert, C., Jarnot, C., Delon, C., Serça, D., Striebig, N., Ferlicoq, M., and Keravec, P.: A new disjunct eddy-covariance system for BVOC flux measurements - validation on $\mathrm{CO}_{2}$ and $\mathrm{H}_{2} \mathrm{O}$ fluxes, Atmos. Meas. Tech., 5, 3119-3132, doi:10.5194/amt-5-3119-2012, 2012.

Benjamin, M. T., Sudol, M., Bloch, L., and Winer, A. M.: Lowemitting urban forests: A taxonomic methodology for assigning isoprene and monoterpene emission rates, Atmos. Environ., 30, 1437-1452, 1996.

Bigi, A., Ghermandi, G., and Harrison, R. M.: Analysis of the air pollution climate at a background site in the Po valley, J. Environ. Monitor., 14, 552-563, 2011.

Blake, R. S., Monks, P. S., and Ellis, A. M.: Proton-Transfer Reaction Mass Spectrometry, Chem. Rev., 109, 861-896, 2009. 
Carslaw, D. C. and Ropkins, K.: openair - an R package for air quality data analysis, Environ. Modell. Softw., 27-28, 52-61, 2012.

Claeys, M., Graham, B., Vas, G., Wang, W., Vermeylen, R., Pashynska, V., Cafmeyer, J., Guyon, P., Andreae, M. O., Artaxo, P., and Maenhaut, W.: Formation of secondary organic aerosols through photooxidation of isoprene, Science, 303, 1173-1176, 2004.

Dalponte, M., Gianelle, D., and Bruzzone, L.: Use of hyperspectral and LIDAR data for classification of complex forest areas, in: Canopy Analysis and Dynamics of a Floodplain Forest, edited by: Gianelle D., Travaglini D., Mason F., Minari E., Chirici G., and Chemini C., Cierre Edizioni, Verona, Italy, 25-37, 2007.

Dalponte, M., Bruzzone, L., and Gianelle, D.: Fusion of hyperspectral and LIDAR remote sensing data for classification of complex forest areas, IEEE Geosci. Remote S., 46, 1416-1427, 2008.

Davison, B., Taipale, R., Langford, B., Misztal, P., Fares, S., Matteucci, G., Loreto, F., Cape, J. N., Rinne, J., and Hewitt, C. N.: Concentrations and fluxes of biogenic volatile organic compounds above a Mediterranean macchia ecosystem in western Italy, Biogeosciences, 6, 1655-1670, doi:10.5194/bg-6-16552009, 2009.

de Gouw, J. and Warneke, C.: Measurements of volatile organic compounds in the earth's atmosphere using proton transferreaction mass spectrometry, Mass Spectrom. Rev., 26, 223-257, 2007.

Decesari, S., Allan, J., Plass-Duelmer, C., Williams, B. J., Paglione, M., Facchini, M. C., O’Dowd, C., Harrison, R. M., Gietl, J. K., Coe, H., Giulianelli, L., Gobbi, G. P., Lanconelli, C., Carbone, C., Worsnop, D., Lambe, A. T., Ahern, A. T., Moretti, F., Tagliavini, E., Elste, T., Gilge, S., Zhang, Y., and Dall'Osto, M.: Measurements of the aerosol chemical composition and mixing state in the Po Valley using multiple spectroscopic techniques, Atmos. Chem. Phys., 14, 12109-12132, doi:10.5194/acp-1412109-2014, 2014.

Derwent, R. G., Jenkin, M. E., Passant, N. R., and Pilling, M. J.: Photochemical ozone creation potentials (POCPs) for different emission sources of organic compounds under European conditions estimated with a Master Chemical Mechanism, Atmos. Environ., 41, 2570-2579, 2007.

Dettmer, K. and Engewald, W.: Adsorbent materials commonly used in air analysis for adsorptive enrichment and thermal desorption of volatile organic compounds, Anal. Biochem., 373, 490-500, 2002.

Ehn, M., Thornton, J. A., Kleist, E., Sipilä, M., Junninen, H., Pullinen, I., Springer, M., Rubach, F., Tillmann, R., Lee, B., LopezHilfiker, F., Andres, S., Acir, I.-H., Rissanen, M., Jokinen, T., Schobesberger, S., Kangasluoma, J., Kontkanen, J., Nieminen, T., Kurtén, T., Nielsen, L. B., Jørgensen, S., Kjaergaard, H. G., Canagaratna, M., Maso, M. D., Berndt, T., Petäjä, T., Wahner, A., Kerminen, V.-M., Kulmala, M., Worsnop, D. R., Wildt, J., and Mentel, T. F.: A large source of low-volatility secondary organic aerosol, Nature, 506, 476-479, 2014.

Fall, R.: Abundant Oxygenates in the Atmosphere: A Biochemical Perspective, Chem. Rev., 103, 4941-4951, 2003.

Fares, S., Park, J.-H., Gentner, D. R., Weber, R., Ormeño, E., Karlik, J., and Goldstein, A. H.: Seasonal cycles of biogenic volatile organic compound fluxes and concentrations in a California citrus orchard, Atmos. Chem. Phys., 12, 9865-9880, doi:10.5194/acp12-9865-2012, 2012.
Fares, S., Schnitzhofer, R., Jiang, X., Guenther, A., Hansel, A., and Loreto, F.: Observations of diurnal to weekly variations of monoterpene-dominated fluxes of volatile organic compounds from mediterranean forests: implications for regional modeling, Environ. Sci. Technol., 47, 11073-11082, 2013.

Fehsenfeld, F., Calvert, J., Fall, R., Goldan, P., Guenther, A. B., Hewitt, C. N., Lamb, B., Liu, S., Trainer, M., Westberg, H., and Zimmerman, P.: Emissions of volatile organic compounds from vegetation and the implications for atmospheric chemistry, Global Biogeochem. Cy., 6, 389-430, 1992.

Finco, A., Coyle, M., Marzuoli, R., Chiesa, M., Loubet, B., DiazPines, E., Gasche, R., Ammann, C., Sutton, M. A., Nemitz, E., and Gerosa, G.: Partitioning of the ozone flux with a mixed deciduous forest in northern Italy - importance of canopy storage and interactions with nitric oxide, to be submitted to Biogeosciences Discuss., 2016.

Foken, T. and Wichura, B.: Tools for quality assessment of surfacebased flux measurements, Agr. Forest Meteorol., 78, 83-105, 1996.

Foken, T., Göckede, M., Mauder, M., Mahrt, L., Amiro, B., and Munger, W.: Post-field data quality control, in: Handbook of Micrometeorology: A guide for surface flux measurement and analysis, edited by: Lee, W. M. X. and Law, B., Dordrecht, Kluer Academic Publishers, 29, 181-203, 2004.

Ghirardo, A., Koch, K., Taipale, R., Zimmer, I., Schnitzler, J.-P., and Rinne, J.: Determination of de novo and pool emissions of terpenes from four common boreal/alpine trees by ${ }^{13} \mathrm{CO}_{2}$ labelling and PTR-MS analysis, Plant Cell Environ., 33, 781-792, 2010.

Goudriaan, J. and van Laar, H.: Modelling Potential Crop Growth Processes. Textbook with Exercises, Kluwer Academic Publishers, Dordrecht, the Netherlands, ISBN 978-0-7923-3220-6, 1994.

Graus, M., Müller, M., and Hansel, A.: High resolution PTR-TOF: Quantification and formula confirmation of VOC in real time, J. Am. Soc. Mass Spectr., 21, 1037-1044, 2010.

Guenther, A., Hewitt, C. N., Erickson, D., Fall, R., Geron, C., Graedel, T., Harley, P., Klinger, L., Lerdau, M., McKay, W. A., Pierce, T., Scholes, B., Steinbrecher, R., Tallamraju, R., Taylor, J., and Zimmerman, P.: A global model for natural volatile organic compound emissions, J. Geophys. Res., 100, 8873-8892, 1995.

Guenther, A., Karl, T., Harley, P., Wiedinmyer, C., Palmer, P. I., and Geron, C.: Estimates of global terrestrial isoprene emissions using MEGAN (Model of Emissions of Gases and Aerosols from Nature), Atmos. Chem. Phys., 6, 3181-3210, doi:10.5194/acp-63181-2006, 2006.

Guenther, A. B., Jiang, X., Heald, C. L., Sakulyanontvittaya, T., Duhl, T., Emmons, L. K., and Wang, X.: The Model of Emissions of Gases and Aerosols from Nature version 2.1 (MEGAN2.1): an extended and updated framework for modeling biogenic emissions, Geosci. Model Dev., 5, 1471-1492, doi:10.5194/gmd-51471-2012, 2012.

Hallquist, M., Wenger, J. C., Baltensperger, U., Rudich, Y., Simpson, D., Claeys, M., Dommen, J., Donahue, N. M., George, C., Goldstein, A. H., Hamilton, J. F., Herrmann, H., Hoffmann, T., Iinuma, Y., Jang, M., Jenkin, M. E., Jimenez, J. L., Kiendler-Scharr, A., Maenhaut, W., McFiggans, G., Mentel, Th. F., Monod, A., Prévôt, A. S. H., Seinfeld, J. H., Surratt, J. D., Szmigielski, R., and Wildt, J.: The formation, properties and im- 
pact of secondary organic aerosol: current and emerging issues, Atmos. Chem. Phys., 9, 5155-5236, doi:10.5194/acp-9-51552009, 2009.

Hansel, A., Jordan, A., Holzinger, R., Prazeller, P., Vogel, W., and Lindinger, W.: Proton transfer reaction mass spectrometry: online trace gas analysis at the ppb level, Int. J. Mass Spectrom., 149/150, 609-619, 1995.

Hayward, S., Hewitt, C. N., Sartin, J. H., and Owen, S. M.: Performance characteristics and applications of a proton transfer reaction-mass spectrometer for measuring volatile organic compounds in ambient air, Environ. Sci. Technol., 36, 1554-1560, 2002.

Hewitt, C. N., Hayward, S., and Tani, A.: The application of proton transfer reaction-mass spectrometry (PTR-MS) to the monitoring and analysis of volatile organic compounds in the atmosphere, J. Environ. Monitor., 5, 1-7, 2003.

Hewitt, C. N., Mackenzie, A. R., Di Carlo, P., Di Marco, C. F., Dorsey, J. R., Evans, M., Fowler, D., Gallagher, M. W., Hopkins, J. R., Jones, C. E., Langford, B., Lee, J. D., Lewis, A. C., Lim, S. F., Mcquaid, J., Misztal, P., Moller, S. J., Monks, P. S., Nemitz, E., Oram, D. E., Owen, S. M., Phillips, G. J., Pugh, T. A. M., Pyle, J. A., Reeves, C. E., Ryder, J., Siong, J., Skiba, U., and Stewart, D. J.: Nitrogen management is essential to prevent tropical oil palm plantations from causing ground-level ozone pollution, P. Natl. Acad. Sci. USA, 106, 18447-18451, 2009.

Horst T. W.: A simple formula for attenuation of eddy fluxes measured with first-order-response scalar sensors, Bound.-Lay. Meteorol., 82, 219-233, 1997.

Jardine, K. J., Monson, R. K., Abrell, L., Saleska, S. R., Arneth, A., Jardine, A., Ishida, F. Y., Serrano, A. M. Y., Artaxo, P., Karl, T., Fares, S., Goldstein, A., Loreto, F., and Huxman, T.: Within-plant isoprene oxidation confirmed by direct emissions of oxidation products methyl vinyl ketone and methacrolein, Glob. Change Biol., 18, 973-984, 2012.

Jordan, A., Haidacher, S., Hanel, G., Hartungen, E., Märk, L., Seehauser, H., Schottkowsky, R., Sulzer, P., and Märk, T. D.: A high resolution and high sensitivity proton-transfer-reaction time-offlight mass spectrometer (PTR-TOF-MS), Int. J. Mass Spectrom., 286, 122-128, 2009.

Junninen, H., Ehn, M., Petäjä, T., Luosujärvi, L., Kotiaho, T., Kostiainen, R., Rohner, U., Gonin, M., Fuhrer, K., Kulmala, M., and Worsnop, D. R.: A high-resolution mass spectrometer to measure atmospheric ion composition, Atmos. Meas. Tech., 3, 10391053, doi:10.5194/amt-3-1039-2010, 2010.

Kalogridis, C., Gros, V., Sarda-Esteve, R., Langford, B., Loubet, B., Bonsang, B., Bonnaire, N., Nemitz, E., Genard, A.-C., Boissard, C., Fernandez, C., Ormeño, E., Baisnée, D., Reiter, I., and Lathière, J.: Concentrations and fluxes of isoprene and oxygenated VOCs at a French Mediterranean oak forest, Atmos. Chem. Phys., 14, 10085-10102, doi:10.5194/acp-14-10085-2014, 2014.

Karl, M., Guenther, A., Köble, R., Leip, A., and Seufert, G.: A new European plant-specific emission inventory of biogenic volatile organic compounds for use in atmospheric transport models, Biogeosciences, 6, 1059-1087, doi:10.5194/bg-6-1059-2009, 2009.

Karl, T. G., Spirig, C., Rinne, J., Stroud, C., Prevost, P., Greenberg, J., Fall, R., and Guenther, A.: Virtual disjunct eddy covariance measurements of organic compound fluxes from a subalpine forest using proton transfer reaction mass spectrometry, Atmos. Chem. Phys., 2, 279-291, doi:10.5194/acp-2-279-2002, 2002.
Karl, T., Guenther, A., Spirig, C., Hansel, A., and Fall, R.: Seasonal variation of biogenic VOC emissions above a mixed hardwood forest in northern Michigan, Geophys. Res. Lett., 30, 2186, doi:10.1029/2003GL018432, 2003.

Karl, T., Potosnak, M., Guenther, A., Clark, D., Walker, J., Herrick, J. D., and Geron, C.: Exchange processes of volatile organic compounds above a tropical rain forest: Implications for modeling tropospheric chemistry above dense vegetation, J. Geophys. Res., 109, D18306, doi:10.1029/2004JD004738, 2004.

Keenan, T., Niinemets, Ü., Sabate, S., Gracia, C., and Peñuelas, J.: Process based inventory of isoprenoid emissions from European forests: model comparisons, current knowledge and uncertainties, Atmos. Chem. Phys., 9, 4053-4076, doi:10.5194/acp-94053-2009, 2009.

Kormann, R. and Meixner, F. X.: An analytical footprint model for non-neutral stratification, Bound.-Lay. Meteorol., 99, 207-224, 2001.

Langford, B., Davison, B., Nemitz, E., and Hewitt, C. N.: Mixing ratios and eddy covariance flux measurements of volatile organic compounds from an urban canopy (Manchester, UK), Atmos. Chem. Phys., 9, 1971-1987, doi:10.5194/acp-9-1971-2009, 2009.

Langford, B., Misztal, P. K., Nemitz, E., Davison, B., Helfter, C., Pugh, T. A. M., MacKenzie, A. R., Lim, S. F., and Hewitt, C. N.: Fluxes and concentrations of volatile organic compounds from a South-East Asian tropical rainforest, Atmos. Chem. Phys., 10, 8391-8412, doi:10.5194/acp-10-8391-2010, 2010a.

Langford, B., Nemitz, E., House, E., Phillips, G. J., Famulari, D., Davison, B., Hopkins, J. R., Lewis, A. C., and Hewitt, C. N.: Fluxes and concentrations of volatile organic compounds above central London, UK, Atmos. Chem. Phys., 10, 627-645, doi:10.5194/acp-10-627-2010, 2010 b.

Langford, B., Acton, W., Ammann, C., Valach, A., and Nemitz, E.: Eddy-covariance data with low signal-to-noise ratio: time-lag determination, uncertainties and limit of detection, Atmos. Meas. Tech., 8, 4197-4213, doi:10.5194/amt-8-4197-2015, 2015.

Lee, A., Goldstein, A. H., Keywood, M. D., Gao, S., Varutbangkul, V., Bahreini, R., Ng, N. L., Flagan, R. C., and Seinfeld, J. H.: Gas-phase products and secondary aerosol yields from the ozonolysis of ten different terpenes, J. Geophys. Res., 111, D07302, doi:10.1029/2005JD006437, 2006.

Lindinger, W., Hansel, A., and Jordan, A.: Proton-transfer-reaction mass spectrometry (PTR-MS): On-line monitoring of volatile organic compounds at pptv levels, Chem. Soc. Rev., 27, 347-354, 1998.

Loreto, F., Fischbach, R. J., Schnitzler, J. P., Ciccioli, P., Brancaleoni, E., Calfapietra, C., and Seufert, G.: Monoterpene emission and monoterpene synthase activities in the Mediterranean evergreen oak Quercus ilex L. grown at elevated $\mathrm{CO}_{2}$ concentrations, Glob. Change Biol., 7, 709-717, 2001.

Luecken, D. J., Hutzell, W. T., Strum, M. L., and Pouliot, G. A.: Regional sources of atmospheric formaldehyde and acetaldehyde, and implications for atmospheric modelling, Atmos. Environ., 47, 477-490, 2012.

Misztal, P. K., Nemitz, E., Langford, B., Di Marco, C. F., Phillips, G. J., Hewitt, C. N., MacKenzie, A. R., Owen, S. M., Fowler, D., Heal, M. R., and Cape, J. N.: Direct ecosystem fluxes of volatile organic compounds from oil palms in South-East Asia, 
Atmos. Chem. Phys., 11, 8995-9017, doi:10.5194/acp-11-89952011, 2011

Monks, P. S., Granier, C., Fuzzi, S., Stohl, A., Williams, M. L., Akimoto, H., Amann, M., Baklanov, A., Baltensperger, U., Bey, I., Blake, N., Blake, R. S., Carslaw, K., Cooper, O. R., Dentener, F., Fowler, D., Fragkou, E., Frost, G. J., Generoso, S., Ginoux, P., Grewe, V., Guenther, A., Hansson, H. C., Henne, S., Hjorth, J., Hofzumahaus, A., Huntrieser, H., Isaksen, I. S. A., Jenkin, M. E., Kaiser, J., Kanakidou, M., Klimont, Z., Kulmala, M., Laj, P., Lawrence, M. G., Lee, J. D., Liousse, C., Maione, M., Mcfiggans, G., Metzger, A., Mieville, A., Moussiopoulos, N., Orlando, J. J., O’Dowd, C. D., Palmer, P. I., Parrish, D. D., Petzold, A., Platt, U., Pöschl, U., Prévôt, A. S. H., Reeves, C. E., Reimann, S., Rudich, Y., Sellegri, K., Steinbrecher, R., Simpson, D., ten Brink, H., Theloke, J., van der Werf, G. R., Vautard, R., Vestreng, V., Vlachokostas, Ch., and von Glasow, R.: Atmospheric composition change - global and regional air quality, Atmos. Environ., 43, 5268-5350, doi:10.1016/j.atmosenv.2009.08.021, 2009.

Moncrieff, J., Clement, R., Finnigan, J., and Meyers, T.: Averaging, detrending, and filtering of eddy covariance time series, in: Handbook of Micrometeorology: A guide for surface flux measurement and analysis, edited by: Lee, W. M. X. and Law, B., Kluer Academic Publishers, Dordrecht, 7-32, 2004.

Müller, J.-F., Stavrakou, T., Wallens, S., De Smedt, I., Van Roozendael, M., Potosnak, M. J., Rinne, J., Munger, B., Goldstein, A., and Guenther, A. B.: Global isoprene emissions estimated using MEGAN, ECMWF analyses and a detailed canopy environment model, Atmos. Chem. Phys., 8, 1329-1341, doi:10.5194/acp-81329-2008, 2008.

Müller, M., Mikoviny, T., Jud, W., D’Anna, B., and Wisthaler, A.: A new software tool for the analysis of high resolution PTR-TOF mass spectra, Chemometr. Intell. Lab., 127, 158-165, 2013.

Neftel, A., Spirig, C., and Ammann, C.: Application and test of a simple tool for operational footprint evaluations, Environ. Pollut., 152, 644-652, 2008.

Nemitz, E., Hargreaves, K. J., Neftel, A., Loubet, B., Cellier, P., Dorsey, J. R., Flynn, M., Hensen, A., Weidinger, T., Meszaros, R., Horvath, L., Dämmgen, U., Frühauf, C., Löpmeier, F. J., Gallagher, M. W., and Sutton, M. A.: Intercomparison and assessment of turbulent and physiological exchange parameters of grassland, Biogeosciences, 6, 1445-1466, doi:10.5194/bg-61445-2009, 2009.

Niinemets, Ü: Research review. Components of leaf dry mass per area - thickness and density - alter leaf photosynthetic capacity in reverse directions in woody plants, New Phytologist, 144, 3547, 1999.

Owen, S. M., Boissard, C., and Hewitt, C. N.: Volatile organic compounds (VOCs) emitted from 40 Mediterranean plant species: VOC speciation and extrapolation to habitat scale. Atmos. Environ., 35, 5393-5409, 2001.

Park, J.-H., Goldstein, A. H., Timkovsky, J., Fares, S., Weber, R., Karlik, J., and Holzinger, R.: Active atmosphere-ecosystem exchange of the vast majority of detected volatile organic compounds, Science, 341, 643-647, 2013.

R Core Team: R: A language and environment for statistical computing. R Foundation for Statistical Computing, Vienna, Austria, ISBN 3-900051-07-0, available at: http://www.R-project. org/ (last access: 18 September 2015), 2012.
Riemer, D., Pos, W., Milne, P., Farmer, C., Zika, R., Apel, E., Olszyna, K., Kliendienst, T., Lonneman, W., Bertman, S., Shepson, P., and Starn, T.: Observations of nonmethane hydrocarbons and oxygenated volatile organic compounds at a rural site, J. Geophys. Res., 103, 28111-28128, 1998.

Rinne, J. and Ammann, C.: Disjunct Eddy Covariance Method, in: Eddy covariance: A practical guide to measurement and data, edited by: Aubinet, M., Vesala, T., and Papale, D., Springer, New York, USA, 291-308, 2012.

Rinne, J., Taipale, R., Markkanen, T., Ruuskanen, T. M., Hellén, H., Kajos, M. K., Vesala, T., and Kulmala, M.: Hydrocarbon fluxes above a Scots pine forest canopy: measurements and modeling, Atmos. Chem. Phys., 7, 3361-3372, doi:10.5194/acp-73361-2007, 2007.

Rinne, J., Douffet, T., Prigent, Y., and Durand, P.: Field comparison of disjunct and conventional eddy covariance techniques for trace gas flux measurements, Environ. Pollut., 152, 630-635, 2008.

Rivera-Rios, J. C., Nguyen, T. B., Crounse, J. D., Jud, W., St. Clair, J. M., Mikoviny, T., Gilman, J. B., Lerner, B. M., Kaiser, J. B., de Gouw J., Wisthaler, A., Hansel, A., Wennberg, P. O., Seinfeld, J. H., and Keutsch, F. N.: Conversion of hydroperoxides to carbonyls in field and laboratory instrumentation: Observational bias in diagnosing pristine versus anthropogenically controlled atmospheric chemistry, Geophys. Res. Lett., 41, 86458651, 2014.

Royal Society: Ground-level ozone in the 21st century: Future trends, impacts and policy implications: Science policy report 15/08, The Royal Society, London, 2008.

Schallhart, S., Rantala, P., Nemitz, E., Taipale, D., Tillmann, R., Mentel, T. F., Loubet, B., Gerosa, G., Finco, A., Rinne, J., and Ruuskanen, T. M.: Characterization of total ecosystem-scale biogenic VOC exchange at a Mediterranean oak-hornbeam forest, Atmos. Chem. Phys., 16, 7171-7194, doi:10.5194/acp-16-71712016, 2016.

Spirig, C., Neftel, A., Ammann, C., Dommen, J., Grabmer, W., Thielmann, A., Schaub, A., Beauchamp, J., Wisthaler, A., and Hansel, A.: Eddy covariance flux measurements of biogenic VOCs during ECHO 2003 using proton transfer reaction mass spectrometry, Atmos. Chem. Phys., 5, 465-481, doi:10.5194/acp-5-465-2005, 2005.

Steinbrecher, R., Smiatek, G., Köble, R., Seufert, G., Theloke, J., Hauff, K., Ciccioli, P., Vautard, R., and Curci G.: Intra- and inter-annual variability of VOC emissions from natural and seminatural vegetation in Europe and neighbouring countries, Atmos. Environ., 43, 1380-1391, 2009.

Taipale, R., Ruuskanen, T. M., Rinne, J., Kajos, M. K., Hakola, H., Pohja, T., and Kulmala, M.: Technical Note: Quantitative long-term measurements of VOC concentrations by PTR-MS measurement, calibration, and volume mixing ratio calculation methods, Atmos. Chem. Phys., 8, 6681-6698, doi:10.5194/acp8-6681-2008, 2008.

Taipale, R., Ruuskanen, T. M., and Rinne, J.: Lag time determination in DEC measurements with PTR-MS, Atmos. Meas. Tech., 3, 853-862, doi:10.5194/amt-3-853-2010, 2010.

Tani, A., Hayward, S., Hansel, A., and Hewitt, C. N.: Effect of water vapour pressure on monoterpene measurements using proton transfer reaction-mass spectrometry (PTR-MS), Int. J. Mass Spectrom., 239, 161-169, 2004. 
Wienhold, F. G., Frahm, H., and Harris, G. W.: Measurements of $\mathrm{N}_{2} \mathrm{O}$ fluxes from fertilized grassland using a fast response tunable diode laser spectrometer, J. Geophys. Res., 99, 1655716567, 1994.

Wohlfahrt, G., Amelynck, C., Ammann, C., Arneth, A., Bamberger, I., Goldstein, A. H., Gu, L., Guenther, A., Hansel, A., Heinesch, B., Holst, T., Hörtnagl, L., Karl, T., Laffineur, Q., Neftel, A., McKinney, K., Munger, J. W., Pallardy, S. G., Schade, G. W., Seco, R., and Schoon, N.: An ecosystem-scale perspective of the net land methanol flux: synthesis of micrometeorological flux measurements, Atmos. Chem. Phys., 15, 7413-7427, doi:10.5194/acp-15-7413-2015, 2015. 